\title{
33 Process-based erosion modelling: promises and progress
}

\author{
B. $\mathrm{Yu}$ \\ Griffith University, Nathan, Australia
}

\section{INTRODUCTION}

Accelerated soil and nutrient losses and their off-site impacts are of great concern for sustainable agriculture and, more generally, for sustainable land management. Prediction of the rate of soil erosion over a range of temporal and spatial scales is important for land use planning, erosion risk assessment, and for evaluating the effects of land use change (Penning de Vries et al, 1998). With urbanisation and population growth in traditionally rural areas, farming on steeplands has continued to increase in recent years, especially in the developing regions of the world (Oldeman et al., 1991; Fisher and Heilig, 1997). In plantation forestry, logging and site preparation activities on steep slopes also expose forested areas temporarily to high risk of soil erosion and nutrient losses (cf. the chapter by Grip et al., this volume)

The most widely used soil erosion prediction technology is the Universal Soil Loss Equation (USLE) (Wischmeier and Smith, 1978) and its successor the Revised USLE (Renard et al., 1997). In recent years, however, a new generation of physically based models such as WEPP (Nearing et al , 1989; Flanagan and Nearing, 1995; Laflen et al., 1997), LISEM (De Roo et al., 1996a), EUROSEM (Morgan et al, , 1998) and GUEST (Misra and Rose, 1996; Rose et al , 1997) has been developed to describe and quantify soil erosion processes. These models are particularly suitable for adaptation across a range of scales in the landscape because physical principles and physically meaningful parameters are involved. In contrast to conceptual runoff and soil erosion models, there are at least three strong arguments in support of approaches based on physical principles and our understanding of the underlying runoff and sediment generation processes. First, physically-based models are more likely to succeed outside the environment in which they were developed, hence more likely to achieve broad applicability. Secondly, model parameters, having clearer physical meaning, may be estimated from measurable variables such as soil hydraulic properties, plant or litter biomass, and various land-use attributes and management practices. Finally, to calibrate conceptual models, long-term experimentation is often required For physically-based models, the period of experimentation, and hence the cost, can be reduced considerably. For example, rainfall simulators can be used effectively to measure runoff, and sediment and nutrient loads during brief intensive campaigns in order to derive the values of key model parameters that may then be used for longer term predictions

There have been a number of reviews of erosion modelling Rose (1985) reviewed developments in soil erosion and deposition models with a particular emphasis on differences in the conceptualisation of water-induced erosion and deposition processes. Bingner (1990) discussed the methods used by such semi-empirical erosion models as CREAMS, SWRRB, EPIC, ANSWERS, and AGNPS. Lane et al. (1992) reviewed the erosion prediction technology as developed within the US Department of Agriculture with particular emphasis on the factor-based USLE/RUSLE, the hybrid approach of the CREAMS model and the process-based WEPP model. Rose (1993) gave a detailed description of the theory underlying GUEST at the time and called attention for the need to better address the issue of erosion prediction at the catchment scale. Rose (1997) further reviewed progress in water and wind erosion modelling. Finally, Coughlan and Rose (1997), and Rose and Yu (1998) summarised research findings of a multiple-country project on soil erosion and sustainable production in tropical steeplands with an emphasis on South East Asia and northeastern Australia

The objectives of this chapter are to define and highlight new developments in erosion modelling techniques that could be considered or used by resource managers to assess erosion risks and evaluate alternative conservation technologies.

\section{AN OVERVIEW OF EROSION MODELLING}

It is useful to classify erosion models according to the conceptual framework in which the model was developed. The first group 
Table 33 1. Erosion rates reported at selected scales for Australia, South East Asia and China

\begin{tabular}{|c|c|c|c|c|c|c|}
\hline Country & Scale & Area $\left(\mathrm{km}^{2}\right)$ & Resolution $\left(\mathrm{m}^{2}\right)$ & Model & $\begin{array}{l}\text { Erosion rate } \\
[\text { t/(ha.yr })]\end{array}$ & References $^{a}$ \\
\hline Australia & National & $7.6 \times 10^{8}$ & $275 \times 275\left(9^{\prime \prime}\right)$ & RUSLE & 6.3 & Luet al, 2001 \\
\hline China & Regional & $2.54 \times 10^{6}$ & - & - & 21 & Wen, 1993 \\
\hline Indonesia & Catchment & $1.35 \times 10^{3}$ & $?$ & USLE & 41 & Agus et al, 1997 \\
\hline Laos & Catchment & 0.67 & - & $?$ & $95 ?$ & $\begin{array}{l}\text { Phanthasith and } \\
\text { Chanthavongsa }\end{array}$ \\
\hline Malaysia & Regional & $8.2 \times 10^{3}$ & $30 \times 30$ & USLE & 13 & Lok and $\mathrm{Li}$ \\
\hline Myanmar & Catchment & $10^{3}-10^{4} ?$ & $?$ & Fournier & $?$ & Htut and Myint \\
\hline Philippines & Catchment & $2.81 \times 10^{2}$ & $100 \times 100 ?$ & 'Modified' USLE & 13 & Collado and Baloloy \\
\hline Thailand & National & $5.13 \times 10^{5}$ & $250 \times 250$ & USLE/RUSLE & 12.5 & $\begin{array}{l}\text { Funnpheng and } \\
\text { Tawanron }\end{array}$ \\
\hline Vietnam & National & $3.31 \times 10^{5}$ & $1000 \times 1000 ?$ & $\begin{array}{l}\text { USLE/nonstandard } \\
\text { application }\end{array}$ & $\sim 10$ & Yu and Lang \\
\hline The World & - & $1.5 \times 10^{10}$ & $?$ & $?$ & 6.3 & Myer's, 1993 \\
\hline
\end{tabular}

${ }^{a}$ Undated authors are participants at the Regional Workshop on Erosion Risk Assessment, Kuala Lumpur, October 2001.

of models includes those of an essentially empirical nature They rely on a comprehensive database to determine the model structure and relevant parameter values. The USLE is a prime example. The second group begins to describe the erosion processes, but still relies on some of the USLE factors to facilitate application in the field. Models in this group are best regarded as hybrid models, i. e. those in a transitional phase leading to full-blown processoriented erosion models. The third and last group represents a new generation of erosion models that breaks away from the factorbased USLE approach. Therefore, physically based erosion models can be simply defined as those that do not contain nor rely on USLE factors. These process-oriented erosion models including GUEST, WEPP and EUROSEM/LISEM are the main focus of this chapter.

It is quite fitting and tempting to begin a review of erosion modelling with the USLE (Wischmeier and Smith, 1965; 1978). Although the USLE may not be the first soil erosion prediction model ever developed (see Renard et al, 1997, for a brief history of erosion prediction equations), it is certainly the best-known and most widely used model, both in the US and elsewhere In the USLE, the following equation is used to predict mean annual soil loss:

$$
A=R K L S C P
$$

where $A$ is the predicted mean annual net soil loss per unit area, $R$ is the rainfall and runoff erosivity factor, $K$ the erodibility factor, $L$ and $S$ are slope length and slope steepness factors, $C$ is the cover and management factor, and $P$ is the support practice factor. Each of these USLE factors was meant to represent and quantify important processes in relation to soil erosion. Because of this particular framework, much of the work to apply and evaluate the USLE was to evaluate these individual factors in different biophysical environments and for different management practices.

The USLE has been used widely in the tropics. The work in West Africa (Roose, 1977) and in Hawaii (El-Swaify and Dangler, 1977) has been widely cited. Lal (1990) provides a good summary of USLE-based erosion research in the tropics Almost all erosion assessments at regional scales were carried out in the USLE framework. Table 33.1 is a recent compilation of estimates of average rates of soil erosion, mostly at the regional scale and in southeast Asian countries. The table shows that the USLE/RUSLE has been used widely in this region for large-scale erosion assessment. The table also shows, interestingly, that at the large scale a typical rate of soil loss is of the order $10-20 \mathrm{tha}^{-1} \mathrm{yr}^{-1}$ for all case studies compiled.

Given that the soil loss is expressed as a product of several independent factors, the USLE is particularly amenable to being used with a geographical information system (GIS) at the catchment and regional scale. The hybrid AGNPS model (Young et al., 1989) is a prime example, while de Roo (1998) and Dickinson and Collins (1998) also presented a number of case studies of this nature. More recently, the RUSLE has been applied with GIS to the entire Australian continent to assess the magnitude and seasonal distribution of rill and sheet erosion (Lu et al, 2001)

This particular factor-based framework has for many years had a profound influence on agricultural research sites around the world where experimental work at the plot and hillslope scale is aimed at demonstrating the effect of certain conservation technologies. Typically, a number of (mostly bounded) runoff plots with similar soil, slope and slope length are established at a site. 
Runoff, soil and nutrient losses, and sometimes crop yields, from these plots are then contrasted to quantify the effectiveness of various treatments imposed at the site (Mutchler et al, 1994). USLE lends considerable support for this type of 'one-factor analysis' of conservation technology in comparison to farmer's conventional practices

Explicit attempts have been made to modify the USLE for small catchments by taking streamflow variables into account (Williams, 1975; Onstad and Foster, 1975; Kinnell, 1997, 1998). The factors considered in the USLE, especially $K$ and $C$, have found their way into quite a few erosion models in which some of the erosion processes are considered. Notable in this group are CREAMS/GLEAMS (Knisel, 1980; 1991), EPIC (Williams et al., 1983), ANSWERS (Beasley et al., 1980), ANSWERS-2000 (Bouraoui and Dillaha, 1996), and CASC2D-SED (Johnson et al. 2000)

As distinct from the factor-based USLE or similar approaches, mean annual soil loss in physically-based erosion models is evaluated as the sum of the soil losses from individual runoff events, $M_{\mathrm{i}}(\mathrm{kg})$. The event soil loss is the product of sediment concentration, $c(t)\left(\mathrm{kg} \mathrm{m}^{-3}\right)$ and runoff rate, $Q(t)\left(\mathrm{m}^{3} \mathrm{~s}^{-1}\right)$ integrated over its duration of $T_{\mathrm{i}}(\mathrm{s})$. Thus:

$$
\begin{aligned}
A & =\frac{1}{N} \sum M_{\mathrm{i}} \\
M_{i} & =\int_{0}^{T_{\mathrm{i}}} c(t) Q(t) d t
\end{aligned}
$$

where $N$ is the number of years to which the mean annual value refers. While Eqns 33.1 and 332 are intended to predict the same long-term average soil loss, the conceptual framework for Eqns 33.2 and 33.3 is fundamentally different from that for the USLE. Equation 333 shows that prediction of the runoff rate has become critical not only because the runoff rate, $Q(t)$, is required explicitly, but because the sediment concentration, $c(t)$, also depends on $Q(t)$ in addition to other variables, such as rainfall intensity, slope and cover: Arguably one of the most distinguishing features between the USLE and the more recently developed process-oriented models is that the USLE assumes or asserts that rainfall characteristics capture all of the climatic and most of the hydrological influences on soil erosion. The rainfall-runoff erosivity factor was intended to quantify the effect of raindrop impact and must also reflect the amount and rate of nunoff likely to be associated with the rain (Renard et al., 1997). In contrast, prediction of runoff amount and runoff rate for individual storm events has become crucial and indispensable to the latest physically-based prediction methods Runoff generation processes and their prediction are highly relevant to erosion modelling (see also the chapter on runoff generation by Bonell, this volume). Figure 33.1 presents a conceptual framework in which the role of runoff is highlighted

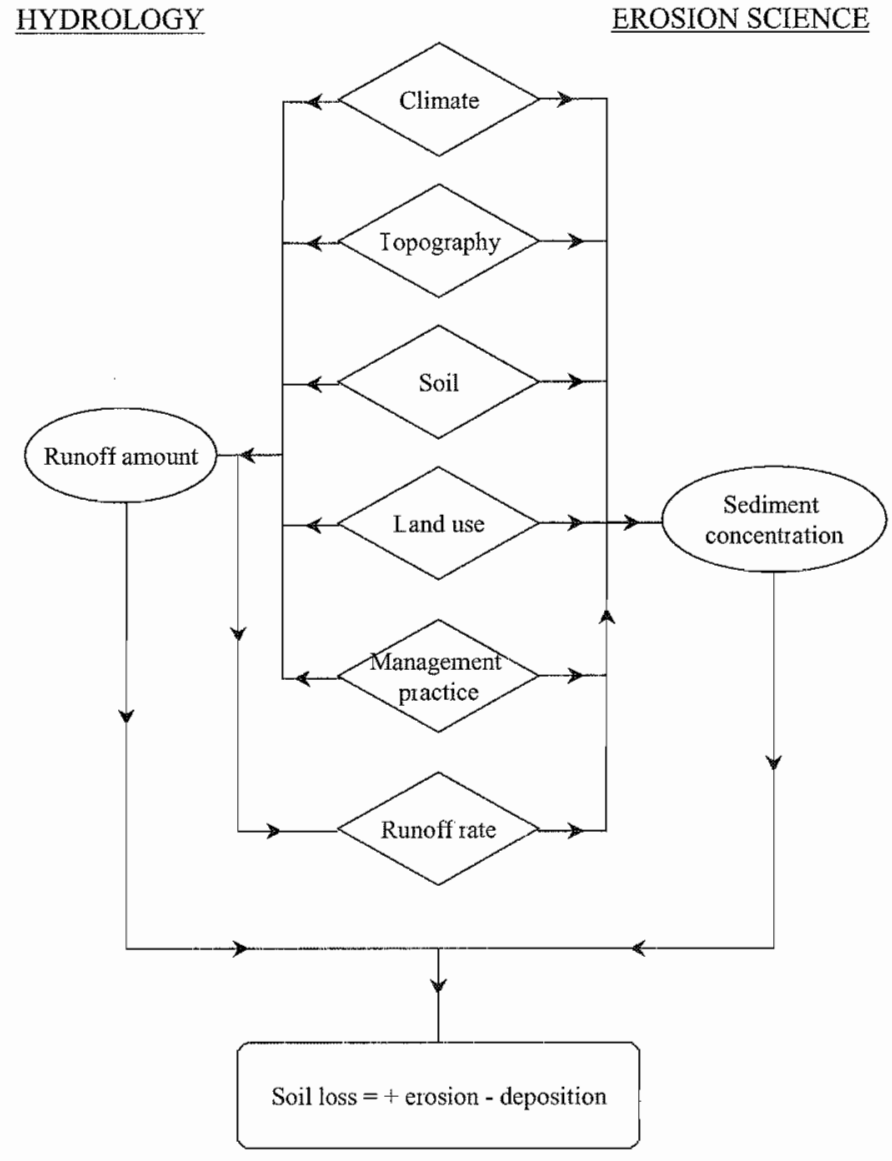

Figure 33.1 A conceptual framework for soil erosion prediction. The role of runoff in erosion prediction is highlighted.

in erosion modelling. It is no exaggeration to say that prediction of water-induced soil erosion is mostly about runoff generation and, to a lesser extent, erosion science. Once this framework for the process-based erosion prediction is established, the description and comparison of a variety of process-based erosion models become much easier because the models differ only in the way in which runoff rate and sediment concentration are predicted

Other landscape erosion models have also been developed on the basis of physical principles. For instance, TOPOG was used to identify erosional hazards in the landscape under steady-state hydrologic conditions (Vertessy et al , 1990; Dietrich et al, 1992; Constantini et al., 1993), while SIBERIA was used to evaluate long-term landscape evolution (Willgoose et al., 1991; Hancock et al, 2002). These models are mostly concerned with the topographical control on runoff generation, and the potential for erosion and sediment transport. In this chapter, these landscape erosion models were excluded deliberately because they do not explicitly address the impacts of land use change (especially the change in management practices) on the rate of erosion and deposition across the landscape 
In the following sections, the theory behind, and application of, four different physically-based soil erosion models are discussed, namely GUEST, WEPP, EUROSEM, and LISEM.

\section{GUEST}

The GUEST erosion model (Griffith University Erosion System Template) was developed originally as a tool to investigate soil erosion processes with measured runoff rate, and event-based average sediment concentration (Rose et al., 1983a; 1983b). The theory behind GUEST has evolved over a period of years and the theory when overland flow is the dominant cause of erosion was described by Hairsine and Rose (1992a and 1992b). There have since been some minor changes, including the introduction of a soil erodibility parameter $\beta$ as a surrogate variable for the original soil erodibility parameter $J$ (Rose, 1993). More recently, the concept of saltation stress (Bagnold, 1977), which can become important when the sediment concentration is high, and the effect of sediment concentration on stream power have been taken into consideration. The theory and parameter sensitivity for both rainfalland runoff driven processes were presented in Misra and Rose (1996), although the latest version of GUEST contains only the module on runoff-driven processes, as these are considered to be dominant on steeplands (Fentie et al., 1997; Rose et al , 1997; Yu and Rose, 1997). Below, the theory underlying GUEST is outlined to show how sediment concentration at the transport limit can be calculated for a given runoff rate, soil type and topography. Although the focus here is on the methodological aspects of GUEST and how the theory can be implemented, it is useful to consider the development of soil erosion and deposition theory over the years in general because GUEST is best regarded as a particular application of that theory.

\section{Theoretical framework for GUEST}

The theory on which GUEST is based begins with a governing equation for soil erosion, transport and deposition:

$$
\frac{\partial\left(c_{i} D\right)}{\partial t}+\frac{\partial\left(c_{i} q\right)}{\partial x}=e_{i}+e_{r i}+r_{i}+r_{r i}-d_{i}
$$

where $D$ is water depth $(\mathrm{m}), q$ is unit discharge, i e flow rate per unit flow width $\left(\mathrm{m}^{2} \mathrm{~s}^{-1}\right), c_{i}$ is the sediment concentration for particle size class $i\left(\mathrm{~kg} \mathrm{~m}^{-3}\right), e_{i}$ and $e_{r i}$ are rates of rainfall detachment and re-detachment $\left(\mathrm{kg} \mathrm{m}^{-2} \mathrm{~s}^{-1}\right), r_{i}$ and $r_{r i}$ are rates of flow entrainment and re-entrainment $\left(\mathrm{kg} \mathrm{m}^{-2} \mathrm{~s}^{-1}\right)$, and $d_{i}$ is the rate of deposition $\left(\mathrm{kg} \mathrm{m}^{-2} \mathrm{~s}^{-1}\right)$. The detachment and entrainment terms are related to the process of dislodging primary particles and aggregates from the original soil. The dislocated particles and aggregates are continuously being retumed to the soil surface under gravity. The processes when these loose, deposited materials are detached once again by the rain or entrained by the flow are called re-detachment and re-entrainment, respectively. Equation 33.4 is based on a mass balance for individual particle size classes. It is necessary to separate sediment into different classes according to their particle size because the associated settling velocity, which characterises the rate of deposition, is closely related to particle size. While there are obvious interactions between rainfall-driven and runoff-driven erosion processes (Moss, 1988; Rose, 1993), in practice relevant theories were developed and tested separately for various scenarios in which either rainfall or runoff dominates the erosion process. For example, Hairsine and Rose (1991) and Proffitt et al. (1991) considered rainfall detachment and deposition in the absence of flow-driven processes, whereas Hairsine and Rose (1992a; 1992b) and Proffitt et al. (1993) developed the theory for soil erosion by overland flow in the absence of rainfall. These studies provided the equilibrium solutions whereby the left hand side of Eqn 33.4 was assumed to vanish. Sander et al. (1996) considered an unsteady situation with sediment concentration varying in time, but assumed that sediment concentration does not vary in space (i e. $\partial c_{i} / \partial x=0$ ). More recently, Eqn 33.4 was solved under steady state conditions (i.e. sediment concentration does not vary with time) to model sediment deposition as a result of an abrupt reduction in slope gradient (Beuselinck et al., 2002a; 2002b; Hairsine et al., 2002; Sander et al., 2002). Sediment deposition has also been modelled resulting from a reduction in velocity due to an abrupt increase in flow resistance (Rose et al., 2002). Table 33.2 summarises these theoretical developments in a chronological order. It can be seen from Table 33.2 that Eqn 33.4 has provided a rich framework to stimulate active research in this area, and allowed examination of various combinations of processes and simplified scenarios.

\section{GUEST methodology}

For practical application of the GUEST theory to tropical steeplands, it is assumed that runoff dominates the erosion process and therefore the first two terms on the right-hand side of Eqn 334 (i.e. detachment and re-detachment by rainfall) are ignored. Furthermore, under equilibrium conditions when sediment concentration does not vary in time and space, the flow entrainment term $\left(r_{i}\right)$ also vanishes because there is no net erosion once equilibrium is reached. This is equivalent to assuming the re-entrainment term $\left(r_{r}\right)$ equal to the rate of deposition. Equation 33.4 thus shows that the settling term due to gravity $\left(d_{i}\right)$ is balanced by the reentrainment term $\left(r_{r i}\right)$ under these conditions. It is further assumed that at equilibrium, a certain fraction of the stream power, $F$, is involved in the re-entrainment of sediment, thus maintaining the sediment in suspension. Stream power is defined here as energy expenditure per unit area and has the unit of $\mathrm{W} \mathrm{m}^{-2}$. Without the 
Table 33.2. Historical development of the erosion and deposition theory from which GUEST was originated

\begin{tabular}{|c|c|c|}
\hline Scenarios & Comments & References \\
\hline $\begin{array}{l}\text { Left Hand Side }(\text { LHS })=0 \\
r_{i}=r_{r i}=0\end{array}$ & $\begin{array}{l}\text { Equilibrium condition } \\
\text { Rainfall-driven }\end{array}$ & $\begin{array}{l}\text { Hairsine and Rose (1991) and Proffitt et al } \\
\text { (1991) }\end{array}$ \\
\hline $\begin{array}{l}\text { LHS }=0 \\
e_{i}=e_{r i}=0\end{array}$ & $\begin{array}{l}\text { Equilibrium condition } \\
\text { Flow-driven in the absence of rain }\end{array}$ & $\begin{array}{l}\text { Hairsine and Rose (1992a and 1992b) and } \\
\text { Proffitt et al. (1993) }\end{array}$ \\
\hline $\begin{array}{l}\partial(c D) / \partial x=0 \\
r_{i}=r_{r i}=0\end{array}$ & $\begin{array}{l}\text { Unsteady, but uniform } \\
\text { Rainfall-driven }\end{array}$ & Sander et al. (1996) \\
\hline$r_{i}=r_{r i}=0$ & Rainfall-driven & Hairsine et al. (1999) \\
\hline $\begin{array}{l}\partial(c D) / \partial t=0 \\
\mathrm{e}_{i}=\mathrm{e}_{r i}=0 \text { slope varying } \\
q \text { constant }\end{array}$ & $\begin{array}{l}\text { Steady and non-uniform } \\
\text { Flow-driven in the absence of rain } \\
\text { Abrupt change in slope gradient }\end{array}$ & $\begin{array}{l}\text { Beuselinck et al. (2002b), Hairsine et al. } \\
\text { (2002), and Sander } \text { et al. (2002) }\end{array}$ \\
\hline $\begin{array}{l}\partial(c D) / \partial t=0 \\
e_{i}=r_{i}=0 \\
q \text { constant }\end{array}$ & $\begin{array}{l}\text { Steady and non-uniform } \\
\text { Combined effects of rain and flow on net deposition }\end{array}$ & Beuselinck et al. (2002a) \\
\hline $\begin{array}{l}\partial(c D) / \partial t=0 \\
e_{i}=e_{r i}=0 \text { slope constant } \\
\text { velocity varying }\end{array}$ & $\begin{array}{l}\text { Steady and non-uniform } \\
\text { Flow-driven in the absence of rain back water effects }\end{array}$ & Rose et al. (2002) \\
\hline$r_{i}=r_{i i}=0$ & $\begin{array}{l}\text { Unsteady, non-uniform } \\
\text { Numerical solution rainfall-driven }\end{array}$ & Hogarth et al. (2002) \\
\hline
\end{tabular}

stream power of overland flow above some threshold value, $\Omega_{0}$ all sediment would eventually have settled out of the overland flow. In short, at equilibrium, the capacity to maintain sediment in suspension is balanced by the downward flux of sediments due to gravity. Thus, it may be shown that:

$$
\frac{\sigma-\rho}{\sigma} c_{\mathrm{t}} g D \phi=F\left(\Omega-\Omega_{0}\right) b
$$

where $c_{\mathrm{t}}$ is the sediment concentration under equilibrium condition $\left(\mathrm{kg} \mathrm{m}^{-3}\right)$, or that at the transport limit (Hairsine and Rose $1992 \mathrm{a} ; 1992 \mathrm{~b}) ; \phi$ is the average settling velocity of all classes when the sediment is divided into size classes of equal mass (Lisle et $a l, 1996)$ and is also known as depositability $\left(\mathrm{m} \mathrm{s}^{-1}\right), \sigma$ and $\rho$ are sediment and water density $\left(\mathrm{kg} \mathrm{m}^{-3}\right)$, respectively, $g$ the acceleration due to gravity $\left(\mathrm{m} \mathrm{s}^{-2}\right) . \Omega$ and $\Omega_{0}$ are stream power and threshold stream power, respectively. In Eqn $33.5, b$ is a shape factor depending on rill geometry (Yu and Rose, 1999) (Table 33 3). Stream power in Eqn 33.5 is given by:

$$
\Omega=\rho g R_{\mathrm{h}} V S
$$

where $R_{\mathrm{h}}$ is the hydraulic radius $(\mathrm{m})$ and $V$ mean flow velocity $\left(\mathrm{m} \mathrm{s}^{-1}\right)$. The term $F\left(\Omega-\Omega_{0}\right)$ can be interpreted as the fraction of the excess stream power that is effective in sediment transport. Eqn 33.5, as given in Hairsine and Rose (1992a), was used to determine the sediment concentration in overland flow at the transport limit up until the mid 1990s at various steepland
Table 33.3. Shape factor $b$ for GUEST

\begin{tabular}{lll}
\hline \hline Rill geometry & Rill shape & Shape factor $b$ \\
\hline Rectangular & $z=0, W_{\mathrm{t}}=W_{\mathrm{b}}$ & $R_{\mathrm{h}} / D$ \\
Trapezoidal rills with steep & $z<z_{0}$ & $R_{\mathrm{h}} / D$ \\
$\quad$ side slopes & & $R_{\mathrm{h}} / D$ \\
$\begin{array}{l}\text { Trapezoidal rills with gentle } \\
\quad \text { side slopes }\end{array}$ & $z<z_{0}$ & \\
Plane (no rills) & $z \rightarrow \infty, R_{\mathrm{h}}=D$ & 1 \\
\hline
\end{tabular}

Source: Yu and Rose (1999).

sites in South East Asia and Australia (Soil Technology, 1995) Complications arise when low runoff occurs in combination with steep slope. Use of Eqn 33.5 would then lead to a physically unrealistic (high) sediment concentration at the transport limit. At small water depth, the $D$ term in Eqn 33.5 can be of the same order of magnitude as the diameter of larger soil particles (aggregates). Thus, when runoff rate, and hence water depth, is low, it is reasonable to expect only the finer soil particles to be fully immersed in the flow and actively involved in the erosion and deposition processes. The effective settling velocity, or the effective depositability $\left(\phi_{\mathrm{e}}\right)$ and the fraction of the eroded soil fully immersed in the flow $(C)$ would be low when the water depth is low. When the effects of a variable water depth and sediment concentration are taken into account, the sediment concentration 
at the transport limit can be written (Rose et al., 1997) as:

$$
c_{\mathrm{t}}=\frac{F b \frac{\sigma}{\sigma-\rho}(1-C)\left(\rho g R S V-\Omega_{0}\right)}{g D \phi_{\mathrm{e}}\left(1+K_{1}-K_{2}\right)}
$$

where the dimensionless term $K_{1}$ is associated with the effect of saltation stress and is given by:

$$
K_{1}=\frac{F b V^{2}(1-C)}{g D}
$$

and the other dimensionless term $K_{2}$ is associated with the consequences of fluid density enhancement by sediment $\left(\rho_{\mathrm{e}}\right)$, and is given by:

$$
K_{2}=\frac{F b R_{\mathrm{h}} S V(1-C)}{D \phi_{\mathrm{e}}} \frac{\sigma}{\sigma-\rho} \frac{\rho_{\mathrm{e}}-\rho}{\rho}
$$

Equation 33.7 , with Eqns 33.8 and 33.9, while not hugely different from Eqn 33.5 under most circumstances, has replaced Eqn 33.5 as a more general expression for the sediment concentration at the transport limit since the mid-1990s at various sites in South East Asia (Coughlan and Rose, 1997; Rose and Yu, 1998; Yu and Rose 1999; Yu et al., 1999).

The sediment concentration at the transport limit (Eqn 33.5 or $33.7)$ is achieved only when the supply of sediments into the flowing water is unlimited. This occurs when the soil surface is free from any contact cover of vegetation, residue or rock fragments, and when the erosion takes place over soils of minimum cohesion, such as freshly tilled soil or newly deposited sediments. The actual sediment concentration from areas without cover, $c_{b}$, can be related to the sediment concentration at the transport limit by a soil erodibility parameter, $\beta$ (Rose, 1993):

$$
c_{\mathrm{b}}=c_{\mathrm{t}}^{\beta}
$$

The higher the erodibility, the higher the sediment concentration for unprotected areas. The theoretical limit is reached when $\beta=1$. The erodibility parameter is broadly related to a more fundamental erodibility parameter, $I$, in terms of the amount of energy required to erode a unit mass of soil (Rose, 1993), and experimental evidence suggests that the soil erodibility parameter $\beta$ depends on soil strength to some extent (Misra and Rose, 1995). Although GUEST allows calculation of the instantaneous sediment concentration if the erodibility parameter is known, measurements of the instantaneous sediment concentration within a runoff event are rarely taken. Usually, only the average sediment concentration on an event basis is available. Instantaneous runoff rates are more readily measured and these can be used to determine the average soil erodibility parameter for the event as a whole

The effect of surface contact cover on soil loss is modelled in GUEST methodology by an exponential function of the form:

$$
c=c_{b} \mathrm{e}^{-\kappa C g}
$$

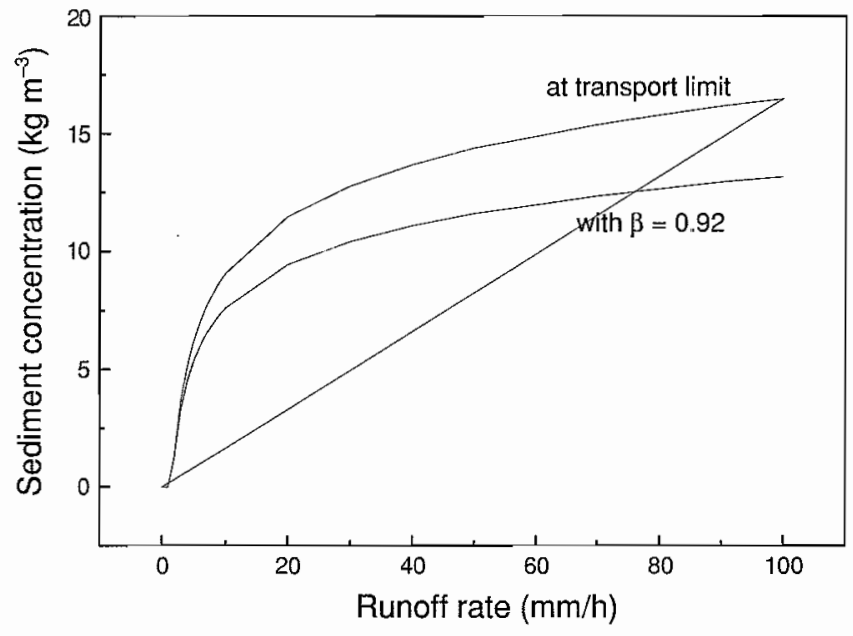

Figure 33.2 The sediment concentration at the transport limit as a function of the runoff rate predicted with Eqn 33.7. Other relevant parameter values are: slope $=5 \%$; slope length $=36 \mathrm{~m}$; Manning's $n=0.03$; average settling velocity $=0.149 \mathrm{~m} \mathrm{~s}^{-1}$; surface contact cover $=10 \%$.

where $C_{\mathrm{g}}$ is the surface contact cover and $k$ an empirically determined coefficient having a value of approximately 0.1 when $C_{\mathrm{g}}$ is measured in percent. For steep slopes, the direct effect of rainfall on soil erosion has been ignored in several recent studies (Soil Technology, 1995). Since sediment concentration due to rainfall detachment is modelled as being linearly proportional to rainfall intensity, the rainfall term can be included if needed. Yu et al. (1999) used the following equation to estimate soil loss while taking into account the effect of both rainfall and runoff:

$$
M=0.01 Q_{\text {tot }}\left(\frac{a P}{3.6 \times 10^{6} \phi}+\lambda c_{\mathrm{t}}^{\beta}\right)
$$

where $M$ is event soil loss in tonnes ha ${ }^{-1}, Q_{\text {tot }}$ is event runoff in $\mathrm{mm}, a$ is soil detachability in $\mathrm{kg} \mathrm{m}^{-3}, P$ the 10 -min peak rainfall intensity in $\mathrm{mm} \mathrm{h}^{-1}$, whereas $\lambda$ is a binary variable assuming a value of 0 or 1 depending on whether or not the direct effect of rainfall is considered. For erosion driven by flow only, $a=0$ and $\lambda=1$. For erosion driven by rainfall only, $\lambda=0$. Use of $\lambda$ introduces additional flexibility in Eqn 33.12 .

To compute the sediment concentration at the transport limit with Eqn 33.7, $F(=0.1$, Proffitt $e t a l ., 1993), \sigma, \rho, g(=9.81 \mathrm{~m}$ $\mathrm{s}^{-2}$ ), and $S$ are input parameters; $V, D, R$ are computed by solving numerically the flow continuity equation, assuming Manning's equation. $\phi_{\mathrm{e}}$ and $(1-C)$ can be calculated using particle size distribution data (Lisle et al., 1996) for given water depth $D$. The rill shape factor $b$ depends on a critical side slope, $z_{0}$ (Yu and Rose, 1997). When rill side slope is less than $z_{0}$, the banks of the rill would be so steep that deposited sediments would not stay on them. Re-entrainment of the eroded material would therefore 
only take place from the bottom of the rill. In the current version of GUEST (Fentie et al., 1997), a critical side slope $z_{0}=1.0$ is assumed. Figure 332 shows a plot of the sediment concentration at the transport limit as a function of the runoff rate to illustrate Eqn 33.7.

Input requirements for Eqn 33.12 fall in three groups: (1) soil properties, (2) topography, (3) hydrology and hydraulics. The minimum data requirement on soil properties includes particle size distribution (both wet-sieved and that resulting from mechanical analysis). The program GUDPRO can be used to determine the fraction of soil immersed $(1-C)$, and the effective sediment depositability, $\phi_{\mathrm{e}}$, as a function of water depth from either wet-sieved size distribution, or from direct measurement of the distribution of settling velocities (Lisle et al., 1996). Soil samples should be taken from the surface layer from which erosion is most likely to occur. The sand fraction $(0.02 \mathrm{~mm})$ can be used to estimate the wet density of the eroded soil particles (Loch and Rosewell, 1992):

$$
\sigma=1460+48^{*} 1.0326^{x}
$$

where $\sigma$ and $x$ are wet density and the percentage of sand grains $(0.02 \mathrm{~mm})$ in the soil, respectively.

Topographical variables in GUEST include slope length, plot width and slope steepness. Plot geometry is characterised by length $(\mathrm{m})$, width $(\mathrm{m})$ and slope $(\%)$. If there are rills, information on rill geometry is also needed The dimension of a rill can be specified by its depth, $D_{\mathrm{r}}$, top and bottom width, $W_{\mathrm{r}}$ and $W_{\mathrm{b}}$, and the inter-rill spacing, $W_{\mathrm{r}}$. The side slope can then be determined by:

$$
z=\frac{W_{\mathrm{t}}-W_{\mathrm{b}}}{2 D_{\mathrm{r}}}
$$

Hydrological and hydraulic variables are runoff rate, $Q$, and Manning's roughness coefficient, $n$. These are used to compute the mean flow velocity, the mean water depth and the hydraulic radius.

\section{Hydrological drivers for GUEST}

It can be seen from the above that runoff rate $Q(t)$ and total runoff amount $Q_{\text {tot }}$ are critical variables in determining soil loss in the GUEST methodology. Although rainfall and runoff rates may vary greatly within a storm event, the temporal variation of sediment concentration, $c(t)$, is not modelled directly. This is partly because generally there are no measurements of sediment concentration within a runoff event, and partly because sediment concentration as a function of time is not needed when the aims are to predict event and long-term soil losses. Instead, an average sediment concentration is sought such that soil loss is the product of this sediment concentration and total nunoff amount. The average concentration is termed the flow-weighted average because it is given by:

$$
\bar{c}=\frac{\int_{0}^{T_{\mathrm{i}}} c(t) Q(t) d t}{\int_{0}^{T_{\mathrm{i}}} Q(t) d t}
$$

To predict this average sediment concentration for individual events, one naturally seeks a single, 'effective' runoff rate that is logically related to this concentration. In GUEST, this effective runoff rate is given by (Ciesiolka $e t a l$, 1995):

$$
Q_{e}=\left[\frac{\int_{0}^{T_{i}} Q^{1.4}(t) d t}{\int_{0}^{T_{\mathrm{i}}} Q(t) d t}\right]^{2.5}
$$

The effective runoff rate is defined in this way so that the relationship between sediment concentration and runoff rate remains essentially invariant, regardless of whether we use steady-state sediment concentration and runoff rate, or the average concentration and effective runoff rate (Yu et al, 1997a). Note that calculation of this effective runoff rate requires flow data for the entire hydrograph, typically at 1-minute intervals (Ciesiolka et al., 1995).

At several experimental sites in Australia and several South East Asian countries, tipping bucket technology was used to measure runoff rate during storm events to meet GUEST data requirements (Ciesiolka et al, 1995; Ciesiolka and Rose, 1997). Where detailed runoff rates are not available, a number of techniques have been developed and tested to estimate the effective runoff rate, depending on the kind of data available. For example, if data on runoff amount and peak rainfall intensity are available, a scaling technique is recommended (Yu et al., 1997a). The effective runoff rate is given by:

$$
Q_{\mathrm{e}}=\alpha\left(\frac{Q_{\mathrm{tot}}}{P_{\mathrm{tot}}}\right) P_{\triangle t}
$$

where $P_{\Delta t}$ is the peak intensity at a particular time interval, $\Delta t$, and $\alpha$ is a scaling coefficient depending on the time interval used. To examine the validity of Eqn 33.17, Yu et al. (1999) used rainfall and runoff data for a total of 180 site-events to estimate the scaling factor $\alpha$ for each of six sites in Australia and South East Asia. The 30 largest events in terms of rainfall total were selected. The same data set was used to develop and validate a rainfall-tunoff model for application at small time scales (Yu et al, 1997b, 1998). The mean annual rainfall for the above sites varies from $1200 \mathrm{~mm}$ to $3500 \mathrm{~mm}$, and long-term runoff coefficients vary from 0.1 to 0.8 (Coughlan and Rose, 1997). Given the considerable range in runoff coefficient, good relationships between the effective runoff rate and the product of the gross 


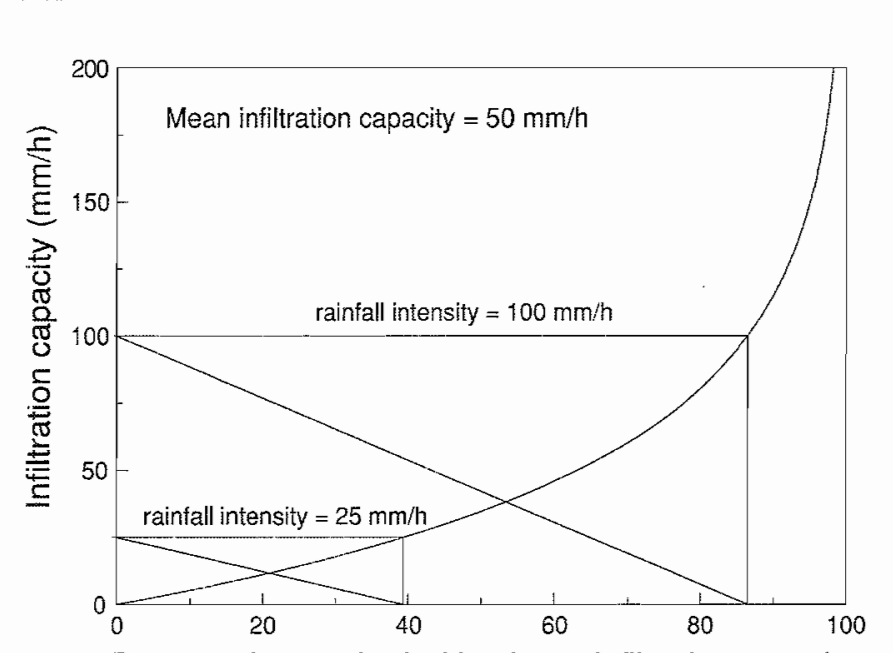

Percent of watershed with a lower infiltration capacity

Figure 33.3 Exponential distribution of infiltration capacity with an average of $50 \mathrm{~mm} \mathrm{~h}^{-1}$.

runoff coefficient and peak rainfall intensity were obtained with $r^{2}$ values of around $0.83-0.84$ for time intervals between 5 to 10 minutes (Yu and Rose, 1999).

At the plot scale, the excess rainfall rate at any point in time can be regarded as the difference between the actual rates of rainfall intensity and infiltration. Yu et al. (1997b) proposed and evaluated a simple infiltration model in which the actual rate of infiltration, $f\left(\mathrm{~mm} \mathrm{~h}^{-1}\right)$, is given as:

$$
f=I_{m}\left[1-\exp \left(-P / I_{\mathrm{m}}\right)\right]
$$

where $P\left(\mathrm{~mm} \mathrm{~h}^{-1}\right)$ is the rainfall intensity and $I_{\mathrm{m}}\left(\mathrm{mm} \mathrm{h}^{-1}\right)$, a parameter representing the spatially averaged maximum rate of infiltration (Yu et al, 1997b). This simple model for actual infiltration shows that at a given rainfall intensity, runoff occurs from a fraction of the area only (Figure 33.3). As the intensity increases, both the runoff area and the runoff rate increase. Actual infiltration also increases with rainfall intensity (Figure 33.3, Eqn 33.18). When the total runoff amount, $Q_{\text {tot }}(\mathrm{mm})$, is known, which is given by the sum of the excess rainfall rates over the entire runoff event, then the parameter $I_{\mathrm{m}}$ can be readily determined by solving the non-linear equation:

$$
Q_{\mathrm{tot}}=\sum_{i=1}^{N}\left\{P_{i}-I_{\mathrm{m}}\left[1-\exp \left(-P_{i} / I_{\mathrm{m}}\right)\right]\right\}
$$

where $N$ is the number of time intervals for the storm event. One of the distinct advantages of Eqn 33.18 is that the model parameter $I_{\mathrm{m}}$ can be determined uniquely from runoff amount, thus removing the need for parameter selection as in the more traditional approaches to modelling infiltration that are used in other models (cf. Table 33.7 ).

Yu et al (1998) compared this model with two other infiltration models (constant runoff coefficient and constant runoff rate) in terms of the hydrographs generated for 30 events at each of the six sites referred to earlier using rainfall and runoff data at time intervals of 1,6, and 15 minutes and found that Eqn 33.18 yielded the best results using the 1-min data, with model efficiency values (Nash and Sutcliffe, 1970) for predicted peak and 'effective' runoff rates of 0.83 and 0.89 , respectively. Fentie et al. (2002) compared eight different methods to estimate peak and effective runoff rates for a pasture catchment in central Queensland and they provided further support for the scaling technique and the spatially variable infiltration model as efficient means of predicting runoff rates for erosion predictions (Fentie et al., 2002). Van Dijk (2002) and van Dijk and Bruijnzeel (2001) applied the spatially variable infiltration model (Eqn 33.18) to experiments on bench terraces in West Java, Indonesia, for prediction of both runoff hydrograph and runoff amount. The model efficiency was typically in the range from 0.72 to 0.82 , suggesting good model performance.

Once the hydrograph is generated, the erosion model within GUEST can be used in the same way as if the runoff rates had been actually measured. Alternatively, if runoff rates have been measured, an effective runoff rate can be computed for each event using Eqn 33.16 before the erosion model is used to determine the sediment concentration at the transport limit

\section{Application of GUEST to tropical steeplands}

To predict soil loss, information on soil erodibility, i.e a value for $\beta$, is required (cf. Eqn 33.10). To evaluate $\beta$, data on runoff rates at small time intervals are needed Rainfall and runoff rates at 1-minute intervals are measured routinely at a series of ACIAR-funded research sites to evaluate soil erodibility parameters (Coughlan and Rose, 1997) (Table 33.4). For sites where data on runoff rate are not available (typical of USLE type of experimentation), the program GOSH (Yu, 1997) can be used first to estimate runoff rates from total runoff amount and rainfall rates before estimating soil erodibility parameters. Therefore, the minimum requirements for hydrological data are rainfall rate at small ( $\leq 30$ minutes) intervals in addition to total runoff amount, $Q_{\text {tot }}$, for each storm event.

Application and validation of GUEST therefore typically involve the following four steps:

- Use GUDPRO (Lisle et al., 1996) to process data on particle size distribution to determine the effective depositability, $\phi_{\mathrm{e}}$, and the fraction of soil immersed, $1-C$, as a function of the water depth, $D$; wet density, $\rho_{\mathrm{s}}$ is also required;

- Use GOSH (Yu, 1997) to process data on rainfall rates and event runoff amount to determine runoff rates as a function of time;

- Assemble information on plot and/or rill geometry before using the programme GUEPS (Yu and Rose, 1997) to estimate the soil erodibility parameter, $\beta$, for the event. 


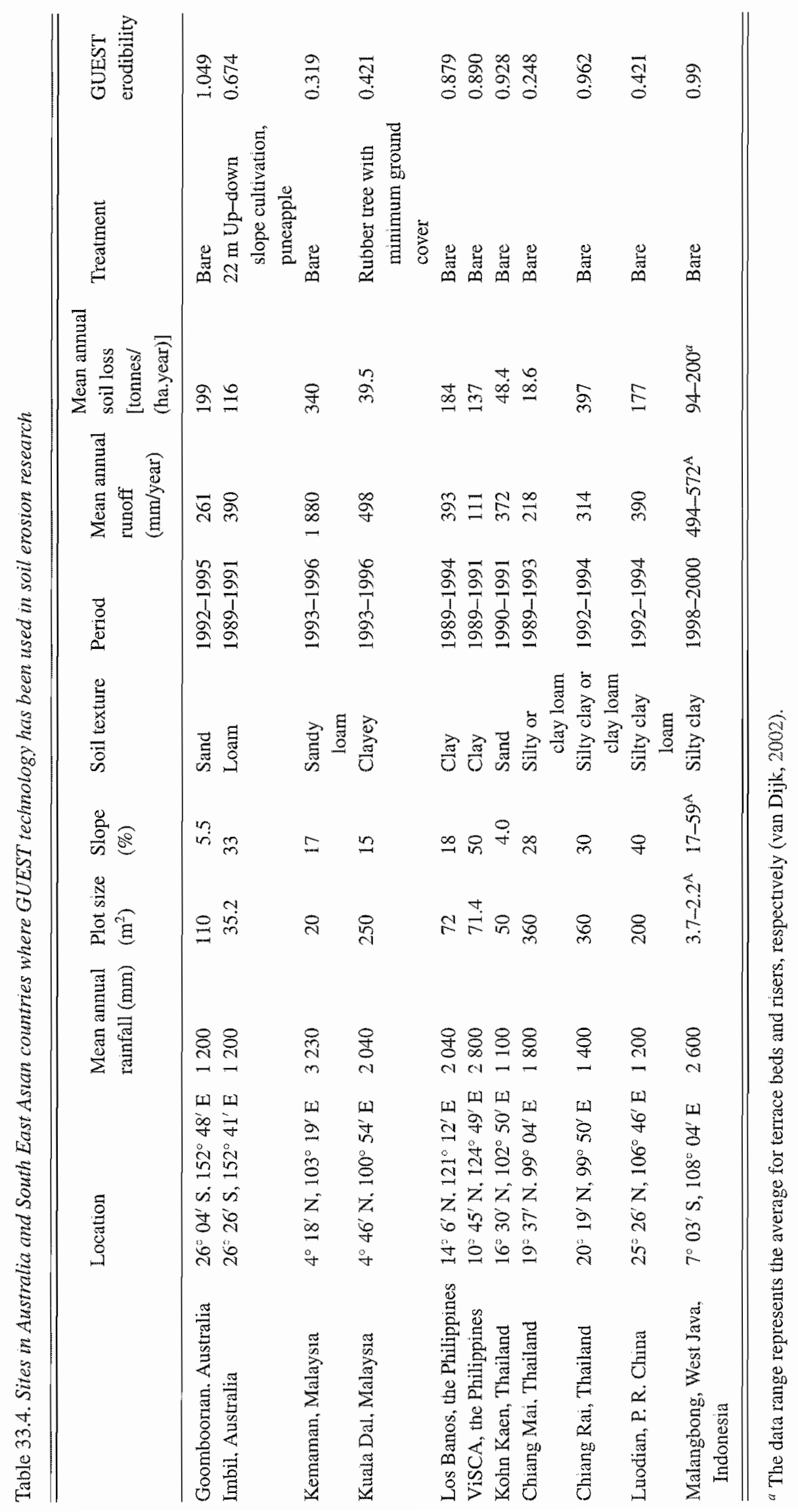




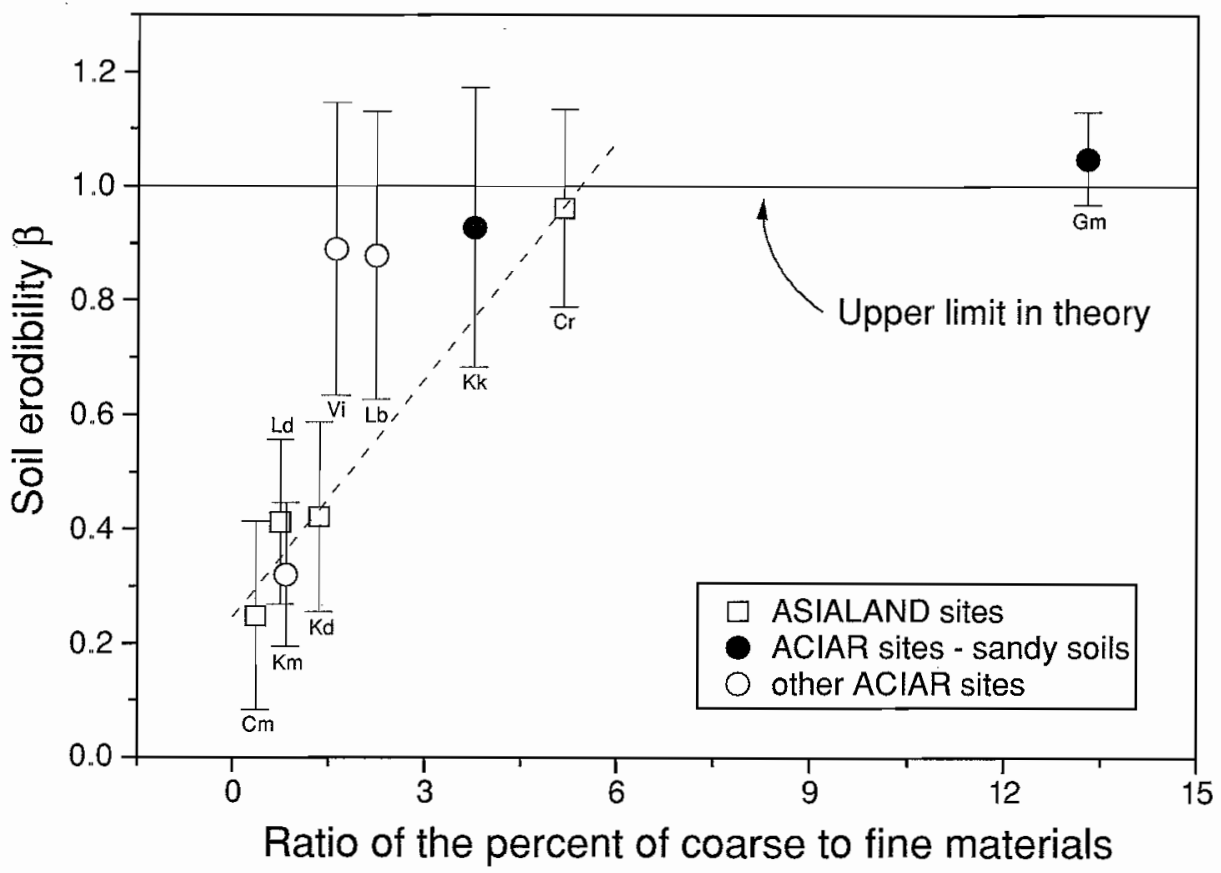

Figure 33.4 The relationship between relative abundance of coarse materials in the soil and soil erodibility $\beta$. (After Figure 9 In Yu et al 1999b.)

- The model can be tested by estimating the amount of soil loss for other events at the same site using the estimated soil erodibility. A stronger test of model performance would involve applying the model and estimated soil elodibility parameter values to adjacent sites with similar soils, and crops/land use.

GUEST, as briefly described in this chapter, has been applied to a number of sites with slope up to $70 \%$ in Australia and various South East Asian countries. Table 33.4 compiles information on these sites including an average erodibility of the soil. When GUEST was used to predict event soil loss using estimated soil erodibility parameters, an average model efficiency of 0.68 was achieved for four sites in China, Malaysia and Thailand (Yu et al., 1999). Predicted soil loss is sensitive to the erodibility value for the event, and the calculated $\beta$ value at the ACIAR and ASIALAND sites in Table 33.4 showed considerable variation from event to event (Soil Technology, 1995; Coughlan and Rose, 1997). Although the average of these event-based $\beta$ values was broadly related to measurable soil properties (Figure 33.4), this relationship has not been tested against observed soil loss in a predictive sense.

Recently, van Dijk and Bruijnzeel (2001) and van Dijk (2002) have developed the GUEST model further for use in bench-terraced terrain in Indonesia by including splash erosion from short, steep slopes as an additional term in Eqn 33. 12. Total storm energy when rainfall intensity exceeded $10 \mathrm{~mm} \mathrm{~h}^{-1}$ was closely related to the observed rate of splash erosion in a volcanic steepland in West Java. Van Dijk et al. (2002) have presented a reformulation of transport by rain splash based on exponential distribution theory. Average model efficiency of the modified GUEST, known as TEST, ranged from 0.47 for the terrace bed and riser, to 0.64 for entire terrace units (van Dijk and Bruijnzeel, 2001).

More recent developments using GUEST include integration into a GIS framework to generate spatial erosion and deposition patterns at the catchment scale (Fentie, 2001) and using the erodibility parameter $\beta$ as a switch from erosion to deposition down a complex hillslope (Siepel et $a l$., 2002). It is, however, also worthwhile to make a number of critical observations. First, the theory on the interactions between rainfall-driven and runoff-driven processes has not been rigorously developed, with most solutions appropriate for either rain-only or flow-only scenarios. Second, the approach to solving the governing equation has been dominated by analytical techniques, which limits the application to all but very simple configurations. Only recently were numerical solutions attempted to examine more complex scenarios (Rose et al., 2002; Hogarth et al., 2004). Finally, all the support for the theory relies on well-controlled flume experiments largely using disturbed soils. Even for these controlled experiments, some of the model parameters were found to vary widely. For instance, the 
fraction of stream power effective in soil entrainment was found to be approximately 0.1 by Proffitt et al. (1993), while a more recent study showed that the fraction ranges from 0.0013 to 0.0075 (Beuselinck et al, 2002a; Hairsine et al, 2002), and there was no obvious explanation of this order-of-magnitude discrepancy.

\section{WEPP}

WEPP (Water Erosion Prediction Project) is a process-based model for runoff and soil erosion prediction developed largely by USDA-Agricultural Research Services with an intention to replace the traditional USLE (Nearing et al., 1989, Laflen et al., 1997). WEPP attempts to model the fundamental erosion processes and to achieve broad applicability in a range of erosion environments such as rangeland. forests and urbanized areas, in addition to the traditional farm fields. WEPP requires none of the factors in USLE/RUSLE By design, WEPP has all the capabilities of USLE/RUSLE, but with considerable added functionality. In particular, WEPP can handle complex hillslope profiles with ease and is able to address the effect of intrinsic or externally imposed climate variability on daily runoff, soil erosion and sediment yield at the hillslope and catchment scale. The Technical Documentation and User Summary (Flanagan and Nearing, 1995; Flanagan and Livingston, 1995) constitute the primary reference materials on WEPP The WEPP program and its documentation are readily available at http://topsoil nserl.purdue edu/."

WEPP can be used to predict soil erosion and net soil loss for individual events or on a continuous daily basis. Normally, ten daily weather variables are used by WEPP to predict the hydrological variables required for soil erosion prediction. The most important of these include daily precipitation amount, storm duration and peak intensity. In addition, WEPP requires information on soil propetties, land use and management practices of particular importance are the effective hydraulic conductivity, rill and interrill erodibility, and the critical shear stress of the soil. Given their strong spatial and temporal variability, these parameters are best calibrated using field data, although empirical relationships are available to estimate these parameters from measurable soil properties such as particle size distribution, organic matter content and cation exchange capacity (Alberts $e t$ al., 1995)

The Green-Ampt infiltration equation under conditions of unsteady rain (Chu, 1978) and kinematic wave theory are used in WEPP to determine runoff amount and peak runoff rate (Stone et al., 1995). The erosion component of WEPP is based on a steady-state continuity equation of the form (Foster et al, 1995):

$$
\frac{\mathrm{d}(c q)}{\mathrm{d} x}=D_{\mathrm{i}}+D_{\mathrm{f}}
$$

where $c$ and $q$ are sediment concentration $\left(\mathrm{kg} \mathrm{m}^{-3}\right)$ and unit discharge $\left(\mathrm{m}^{2} \mathrm{~s}^{-1}\right)$, respectively, $D_{\mathrm{i}}$ the interrill erosion rate, and $D_{\mathrm{f}}$ rill erosion rate. The term steady state implies that these variables are assumed not to vary in time within each runoff event, but can vary in the downslope direction $(x)$ only. The interrill erosion rate is modelled as being proportional to the product of rainfall intensity and runoff rate:

$$
D_{\mathrm{i}}=K_{\mathrm{iadj}} I_{\mathrm{e}} Q S_{\mathrm{d}} F_{\mathrm{n}}(W / W r)
$$

where $K_{\text {iadj }}$ is the adjusted interrill erodibility $\left(\mathrm{kg} \mathrm{s} \mathrm{m}^{-3}\right), I_{\mathrm{e}}$ effective rainfall intensity $\left(\mathrm{m} \mathrm{s}^{-1}\right), Q$ interrill runoff rate $\left(\mathrm{m} \mathrm{s}^{-1}\right), S_{\mathrm{d}}$ the interrill sediment delivery ratio, and $F_{\mathrm{n}}$ accounts for irrigation nozzle impact energy variation. $W$ and $W r$ are rill spacing and rill width, respectively. Effective rainfall intensity is defined in WEPP as the average intensity for the duration when rainfall rate exceeds infiltration rate. Interrill sediment delivery ratio, $S_{\mathrm{d}}$, depends on interrill roughness factor, settling velocity and fractions of five size classes considered in WEPP (Flanagan and Nearing, 2000) The rill erosion rate is given as:

$$
D_{\mathrm{f}}=K_{\mathrm{r}}\left(\tau-\tau_{\mathrm{c}}\right)\left(1-c / c_{\mathrm{t}}\right)
$$

where $K_{\mathrm{r}}$ is the rill erodibility parameter $\left(\mathrm{s} \mathrm{m}^{-1}\right), \tau$ flow shear stress (Pa) and $\tau_{\mathrm{c}}$ is the critical flow shear stress (Pa). When the actual sediment concentration $c$ exceeds that at transport capacity, $c_{\mathrm{t}}$, deposition occurs and $D_{\mathrm{f}}$ becomes negative and is given by:

$$
D_{\mathrm{f}}=\phi\left(c_{\mathrm{t}}-c\right)
$$

where $\phi$ is the average settling velocity $\left(\mathrm{m} \mathrm{s}^{-1}\right.$ )

The concentration at the transport limit in WEPP is determined using Yalin's equation (Yalin, 1963) as formulated by Foster (1982)

For each runoff event, the peak runoff rate is considered the 'representative', steady-state runoff rate while effective runoff duration is the runoff amount divided by this representative runoff rate.

To evaluate the predictive capabilities of WEPP, predicted runoff and soil loss have been compared with measurements at a number of sites in the United States. Ghidey and Alberts (1996) compared measured and predicted runoff and soil loss from cultivated fallow, corn and soybean cropping systems for a site in Missouri, and found that WEPP tends to over-predict runoff and soil loss in dry years, but overall the model's performance was satisfactory. Zhang et al (1996) and Liu et al (1997) validated WEPP at the hillslope and catchment scale, respectively. Zhang et al. (1996) used data for 4124 events from 556 plot years and eight locations to evaluate WEPP runoff and soil loss predictions. Runoff and soil loss data used in this study were all collected from the standard USLE plots. They noted that WEPP over-predicted 
runoff for small events and under-predicted for large events. Using internally estimated hydraulic conductivity values, they were able to obtain an $r^{2}$ value of 0.67 for Iunoff for 491 selected events, and 0.40 for event soil loss. Tiwari et al. (2000) extended the work by Zhang et al. (1996). They used more than 1600 plotyears data from 20 locations and compared WEPP with the USLE and RUSLE in terms of soil loss prediction. For annual soil loss, the $r^{2}$ value for WEPP was 0.43 , which was lower than for the USLE $(0.58)$ and RUSLE $(0.62)$. On a mean annual basis, the $r^{2}$ for WEPP was 0.72 . This again was lower than that for the USLE $(0.80)$ and RUSLE (0.75). Overall, WEPP did not perform as well as the USLE for the sites included. Liu et al. (1997) used data from 15 small catchments (0.35-5.14 ha) and obtained $r^{2}$ values of 0.86 for total runoff and 0.91 for total sediment for these catchments. On a runoff event basis, the $r^{2}$ values ranged from 0.01 to 0.8 for runoff and 0.02 to 0.90 for sediment yield. Bjorneberg et al. (1999) tested WEPP for furrow irrigation from three field sites in Idaho. They calibrated WEPP using data from the upper quarter of two fields and used the calibrated parameter values for effective hydraulic conductivity, critical shear stress and rill erodibility to predict runoff and soil loss at field ends. They noted that the calibrated rill erodibility was some 100 times smaller than the recommended value for the soil, and the predicted infiltration remained essentially constant (around $50 \mathrm{~mm}$ ), and not nearly as variable as the observed infiltration (about $35-90 \mathrm{~mm}$ ). At the field ends, WEPP over-predicted soil loss and under-predicted runoff: The $r^{2}$ values ranged from 0.08 to 0.44 for soil loss and from 0.02 to 0.86 for runoff Kincaid (2002) further demonstrated WEPP's capability to predict runoff and soil erosion under sprinkler irrigation and found that prediction variability for individual furrows was high. Such findings are expected given the inherent spatial variability in the rate of infiltration at the ficld scale. It was recommended that WEPP is best used to indicate when serious runoff is likely to occur under sprinkler irrigation for different soils and crop management practices.

Elsewhere in the world, several attempts have also been made to test, validate, and use WEPP for runoff and soil loss predictions. Povilaitis et al. (1995) applied WEPP to five runoff and erosion plots in Lithuania and found that WEPP performed fairly well. Klik et al. (1997) found that the interrill erodibility needed re-calibration for two sites in Austria: runoff was better predicted $\left(R^{2}=0.98\right)$ than soil loss. Soto and Diaz-Fierros (1998) presented an interesting case study of the effects of bush fire on runoff and soil loss and subsequent forest regeneration in Spain. They demonstrated the applicability of WEPP in addressing some of the management issues as being much wider than what can be dealt with using conventional erosion prediction technology such as the USLE/RUSLE. In Australia, Yu et al. (2000) applied WEPP to a pineapple farm in south-east Queensland to determine its predictive potential in a hitherto untested biophysical environment.
The average coefficient of efficiency (Nash and Sutcliffe, 1970) for runoff and soil loss prediction was -0.02 using soil property based parameter values, and 0.66 using calibrated parameter values. Yu and Rosewell (2001) validated WEPP using runoff and soil loss data for bare fallow and winter wheat plots in southeastern Australia (New South Wales). Model parameter values were derived directly from soil properties rather than from calibration. For the latter site, in contrast to the site in southeast Queensland which had a sandy soil, WEPP worked quite well. Model efficiency was 0.97 , both for predicted runoff and soil loss from bare fallow plots, in contrast to an average of -0.02 for the pineapple site in southeast Queensland. WEPP was also able to reproduce the effect of slope length on sediment concentration at the NSW site. This study provided additional information to establish the relationships between WEPP parameters and specific soil properties without which WEPP can never be used in a truly predictive sense. In New Zealand, Su et al. (1999) found that for a wellstructured clayey soil (clay content $66 \%$ ), the baseline hydraulic conductivity was under-estimated using soil properties resulting in an over-prediction of runoff from a bare plot near Auckland (slope $14 \%$, area $13.1 \mathrm{~m} \times 3.1 \mathrm{~m}$ ). More recently, use of WEPP to simulate runoff and soil loss was attempted at Perieni station, in eastern Romania (Popa, 2002). Considerable difficulties were encountered, especially with preparing climate inputs for WEPP and in the end, CLIGEN-generated climate data for one site in Nebraska, USA, with similar average precipitation and temperatures, were used. WEPP tended to over-predict runoff for fallow, corn, winter wheat and bean crops, and under-predict soil loss for the same treatments. The quality of the simulated runoff and soil loss was difficult to assess for this Romanian site because of the problems with input preparation for WEPP. Given the inconsistent model performance, there is a need to continue to validate various components of WEPP for a range of climates, topography, soils, land uses and management practices, particularly in the humid tropics.

Recently, a trimmed-down version of WEPP, known as HEM (Hillslope Erosion Model) has been developed and adapted for rangeland (Lane et al , 1995; 2002). On-line application of HEM is available at http://eisnr.tucson ars ag gov/hillslopeerosionmodel/ Cogle et al. (2001) tested HEM at one site each in India, Australia and New Zealand. The calibrated erodibility values for tropical sites in Australia and India were much lower (by a factor of 6.1-15) than the default values for texturally similar soils. Unvalidated HEM and WEPP applications using GIS (ArcInfo/ArcView) have been performed by Wilson et al. (2001) and Flanagan et al. (2001). Another noticeable development is the possibility to run WEPP live on the Web, either as a general application or as a customised application in a forested environment (http:// octagon nserl purdue edu/weppV1/; http://forest moscowfsl wsu edu/fswepp/). 


\section{EUROSEM AND LISEM}

LISEM (LImburg Soil Erosion Model) was developed at Utrecht University in the Netherlands (de Roo et al., 1996a, b), while EUROSEM (EUROpean Soil Erosion Model) is primarily a result of the collaborative efforts from a number of countries in the European Community (Morgan et al., 1998), and the USDA. These two models are discussed together because they show considerable similarity in terms of the approach adopted, the science used and applicability intended.

Both are single-event runoff and erosion simulation models. Rainfall, topographical and soil data along with a number of model parameters are used to simulate time series of runoff rate and sediment concentration during a storm event. Hydrographs and sedigraphs, as well as maps showing areas of net erosion and net deposition are standard model outputs.

Local net erosion rate, $e$, is modelled in both models by:

$$
e=e_{\mathrm{r}}+e_{\mathrm{f}}
$$

where $e_{\mathrm{I}}$ is a rainfall detachment term and always positive, and $e_{f}$ is the flow detachment term, which can be either positive for erosion, or negative for deposition when the sediment concentration exceeds that at the transport capacity. The rainfall detachment term is modelled mainly as a function of rainfall kinetic energy, but reduced as water depth increases. The flow detachment term is modelled as a linear function of the difference between sediment concentration at the transport limit, $c_{\mathrm{t}}$, and actual sediment concentration, $c$, i.e:

$$
e_{\mathrm{f}} \propto \phi\left(c_{\mathrm{t}}-c\right)
$$

where $\phi$ is the average settling velocity (essentially depositability in the context of GUEST). Both EUROSEM and LISEM use the set of equations for $c_{\mathrm{t}}$ as a function of the unit stream power developed by Govers (1990). Some minor differences in erosion modelling between the two erosion models include an additional option in EUROSEM of using Everaert (1991)'s equation for interrill transport capacity.

Both models use similar methods to simulate rainfall interception by vegetation and surface depression storage and both use Manning's equation and a kinematic wave approximation to determine surface runoff hydrographs. However, the two models differ in the infiltration models used to calculate the rainfall excess. EUROSEM uses the infiltration equation developed by Smith and Parlange (1978) as in KINEROS/KINEROS2 (Woolhiser et al., 1990; Smith et al., 1995), while LISEM has a number of options including the Holtan (1961) equation as used previously in ANSWERS (Beasley et al, 1980), as well as the well-known Green-Ampt and Richards equations.
The major difference between the two models is that EUROSEM describes the flow and sediment routing capabilities within a catchment using flow elements which are either planes or channels following the method used in KINEROS and KINEROS2 (Woolhiser et al., 1990; Smith et al , 1995). LISEM, like ANSWERS, uses regular grid cells to represent the catchment In addition, LISEM is tightly coupled with PCRaster. PCRaster is a raster-based spatial modelling system that has extensive cartographical, dynamic and geo-statistical modelling capabilities (Wesseling et al, 1996; van Deursen, 1995). It has been used not only for hydrological and erosion modelling but also for flood simulation in large basins (de Roo et al , 2000).

EUROSEM and LISEM have been calibrated and validated mostly in the UK and the Netherlands at plot to catchment scales (Morgan et al., 1998; Folly et al., 1999, de Roo et al., 1996b; de Roo and Jetten, 1999). In addition, Quinton and Morgan (1998) tested EUROSEM for the C-3 catchment, Oklahoma, whereas Albaledejo et al. (1994) applied EUROSEM in Spain at the plot scale $\left(75 \mathrm{~m}^{2}\right)$. De Roo and Jetten (1999) also presented the validation results using LISEM for a $0.69 \mathrm{~km}^{2}$ catchment in South Africa. Lately, Hessel (2002) attempted to apply LISEM to a 3.5 $\mathrm{km}^{2}$, deeply dissected catchment on the loess plateau in China and he argued for the need to modify a number of components of LISEM to simulate runoff, soil erosion and transport better in this environment, known for its high erosion rates. While these modifications are well justified on theoretical grounds, both the existing and modified versions of LISEM require calibration. Interestingly, there is no noticeable improvement in terms of the calibrated hydrographs and sedi-graphs when the modified version of LISEM was used (Hessel, 2002). Stolte et al. (2002) reported an attempt to calibrate LISEM for a 9 ha catchment near Chengdu, Sichuan Province, China, and then apply LISEM to quantify runoff and soil loss for a $7 \mathrm{~km}^{2}$ catchment in which the catchment for calibration is located. The simulated hydrograph for calibration was highly fluctuating and much more responsive to rainfall than the measured hydrograph for the 9 ha catchment. Calibration results for soil loss were not reported for this catchment (Stolte et al., 2002)

Of the three small catchments instrumented for the LISEM project in the southern hilly region of the Netherlands, the Catsop catchment $\left(0.45 \mathrm{~km}^{2}\right)$ was used for calibration and validation of a number of erosion prediction models (Catena, 1999). Five events were used for model calibration and five additional events were reserved for validation purposes. Table 33.5 shows the percentage differences between simulated and measured values for five validation events using EUROSEM and LISEM for this catchment. It can be seen that EUROSEM tends to over-estimate runoff and soil loss, a trend which is consistent with the findings of Albaledejo et al. (1994) in Spain, while LISEM tends to under-estimate them 


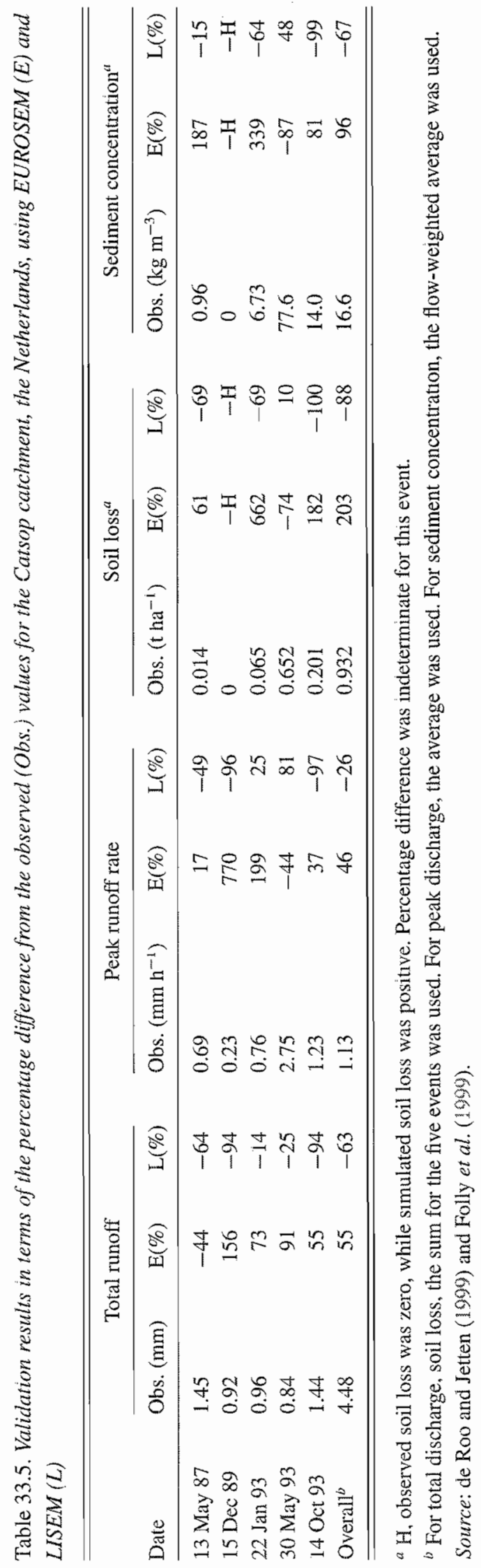


Table 33.6. A comparison of two alternative process-based approaches to water erosion and deposition modelling

\begin{tabular}{|c|c|c|}
\hline Model & GUEST & WEPP \\
\hline \multirow[t]{3}{*}{ Equivalent conceptions } & Rainfall-dominated processes & Interrill erosion \\
\hline & Lateral sediment input & Interrill sediment delivery \\
\hline & Runoff-dominated processes & Rill erosion and deposition \\
\hline \multirow{2}{*}{ Concentration at transport limit, $c_{\mathrm{t}}$} & $\sigma b F\left(\Omega-\Omega_{0}\right)$ & $T_{\mathrm{c}} / q$ with $T_{\mathrm{c}}$ being a calculable quantity \\
\hline & $\overline{(\sigma-\rho) g D \phi}$ & from flow and soil characteristics \\
\hline Flow entrainment/detachment & Proportional to excess stream power & Proportional to excess shear stress \\
\hline Parameters for flow entrainment/detachment & $F J^{-1}$ & $K_{\mathrm{I}}$ \\
\hline Sedimentation & Proportional to $c_{\mathrm{t}}$ & Proportional to $c_{t}$ \\
\hline Parameters for sedimentation & $\phi$ & $\phi$ \\
\hline Rain detachment & Proportional to rainfall intensity & Proportional to rainfall intensity \\
\hline Parameters for rain detachment & $H a_{\mathrm{d}} \phi^{-1}$ & $K_{\mathrm{i}}$ \\
\hline
\end{tabular}

for the same events. More importantly, the percentage differences between measured and predicted values are quite large for both models. Favis-Mortlock et al. (1996) and Jetten et al. (1999) addressed a number of issues associated with model validation at field and catchment scales.

Takken et al. (1999) reported a most interesting and unique evaluation study of LISEM for an extreme storm event on a $2.96 \mathrm{~km}^{2}$ catchment in Belgium. They surveyed erosion and deposition areas after the storm and calibrated the Green-Ampt infiltration parameters in LISEM so that the simulated total sediment yield from the catchment equalled the observed sediment yield. Spatially uniform rainfall at a rather coarse temporal resolution $(0.5 \mathrm{~h})$ was used to drive the erosion model for the catchment. Saturated hydraulic conductivity, as well as initial and saturated soil moisture contents were assumed to be homogeneous over the entire catchment. The simulated erosion rates for individual land units were poor. While the model reproduced the overall sediment delivery for the catchment (by necessity because the model was calibrated this way), a comparison of the simulated and observed spatial distributions of erosion and deposition within the catchment showed that the model over-estimated considerably the spatial extent of deposition and under-estimated the depth of deposition where deposition actually occurred. This study highlights the need to compare the spatial distributions of erosion and deposition rates, and the inadequacy of model validation using data collected at the catchment outlet alone (cf van Dijk, 2002)

\section{A COMPARISON OF EROSION PREDICTION MODELS}

Recent work has shown that the basic equation of GUEST (Eq. 33.4 ) is essentially equivalent to the erosion and deposition equations (30-33) used in WEPP under steady-state conditions
$(\mathrm{Yu}, 2003)$. In particular, the rainfall-driven terms (i.e. rainfall detachment $e_{i}$ and re-detachment $e_{d i}$ ) in Eqn 33.4 can be interpreted as representing the lateral sediment input from the interrill area in WEPP, while the runoff-driven processes in rills or preferred flow pathways in the context of GUEST (i.e $r_{i}, r_{r i}$ and $d_{i}$ in Eqn 33.4) are equivalent to the rill erosion and deposition in WEPP (equations 33.22 and 3323 ). There are also considerable similarities between GUEST and WEPP in terms of how the individual processes are parameterised (Table 33.6). For instance, the rill erodibility in WEPP, $K_{r}$, is broadly related to $F / J$ in GUEST, where $J$ is the specific energy of entrainment (Hairsine and Rose, 1992a; Rose 1993). The similarity between GUEST and WEPP is not a coincidence, since the governing equations for both models are based on mass balances. The implication of this similarity is that choosing a particular model may be not nearly as important as how individual erosion processes are formulated and whether the parameter values are widely available to promote model use.

In practice, WEPP offers considerable applicability in terms of representing complex topography, climate variability, or various land use and management scenarios. WEPP can be quite useful for resource managers when a database for input parameter values has been prepared. Overall, WEPP is currently too complex, and hence too rigid, to be ideal for research purposes, while at the same time not simple enough in terms of the demand for data to be adopted widely for routine applications in less developed regions of the world. In contrast, GUEST and the theoretical framework from which GUEST was derived are ideal tools for erosion research. They allow exploration of various sub-processes in erosion and deposition and their interactions. However, because there is a general lack of methods for the determination of parameter values from measurable soil properties and land use practices for GUEST, it will require considerable effort to use GUEST in a predictive sense without prior calibration against field measurements. 
Schröder (2000) compared WEPP, EUROSEM and Erosion2D (Schmidt, 1996) in terms of their model components. Sensitivity analysis strongly suggested that predictions are particularly sensitive to infiltration-related parameters for all models Runoff and soil loss data collected under a rainfall simulator at two sites in Germany were used to evaluate the three models without calibration. In terms of model efficiency (Nash and Sutcliffe, 1970), WEPP performed better for runoff prediction for a silt loam while EUROSEM was better for a sandy loam. WEPP over-predicted sediment concentration by a factor of 2 . For EUROSEM, the predicted concentration depends on which transport equation is used and whether rills are assumed to be present. Better results can be achieved using Govers' (1990) equation while assuming that no rills exist, although the equation was originally developed for rills. The large difference in predicted and measured runoff has precluded any meaningful comparison in terms of soil loss (Schröder, 2000). Kandel et al. (2001) selected several equations from GUEST, WEPP and EUROSEM to fit the plot data from Nepal, and showed that for these physically-based models, high-resolution (2-min) rainfall and runoff were needed. Using daily data would lead to a noticeable deterioration in model performance.

A comparison of all the erosion models discussed in this chapter is presented in Table 33.7 including those that combine the USLE factors with sub-models for various hydrological and erosion processes.

\section{A CRITIQUE OF PHYSICALLY BASED} EROSION MODELLING

In this section, we attempt to identify the challenges facing all those working with physically based models for soil erosion prediction. These challenges also serve to indicate the areas in which improvements in the current suite of physically based erosion models are likely to occur.

\section{Different mechanisms}

Different mechanisms of runoff generation have not received sufficient attention in physically based erosion models (Table 33.7). As argued throughout this chapter, runoff generation plays a crucial role in determining the magnitude and location of erosion and deposition in the landscape. It can be said that the ability to predict runoff rate determines and limits the potential of all erosion prediction models. Various aspects of runoff generation in the humid tropics are addiessed by Bonell in this volume. It is, however, worthwhile to highlight a common trend in erosion models to over-emphasise the importance of Hortonian overland flow as evidenced by the various classic infiltration equations that are used (Table 33.7). Infiltration excess is often the only process considered in erosion modelling. This is at least in part because most fundamental erosion research has been carried out at the plot scale with a minimum of vegetation cover. Under such conditions surface runoff is indeed often generated by the Hortonian mechanism in which the infiltration capacity is exceeded by rainfall intensity. At the catchment scale, and in rainforest environments especially, however, for most of the catchment and for most of the time, runoff occurs only where an area is locally saturated. It is widely documented that in forested and humid environments, Hortonian flow in fact rarely occurs (Bonell, this volume). However, in deforested tropical uplands where valley bottoms are often narrow and slopes straight to convex, opportunities for the generation of saturated overland flow (SOF) are usually limited (cf. Dunne, 1978; Bruijnzeel, 1990). Under such conditions, stormflow at the headwater catchment scale represents a mixture of rapid subsurface stormflow ('throughflow') and, depending on the degree of surface disturbance, Horton overland flow generated on impervious surfaces (trails, roads, settlements) and agricultural fields (Rijsdijk and Bruijnzeel, 1990; Ziegler et al., 1997; Purwanto, 1999). Although SOF and the associated erosion processes have not been accommodated at all in any of the physically based erosion models discussed in the previous section, the controlled experimental results of Huang et al. (1999) have shown that much higher erosion rates occurred from discharge areas generating SOF compared to recharge areas. It is imperative to incorporate necessary switches between the two different mechanisms for runoff generation in response to changes in topography, vegetation cover, land use and management practices (cf. Vertessy et al., 1990)

\section{Overland flows}

Overland flow shows highly complex and irregular hydraulic characteristics (Abrahams and Parsons et al, 1994). With respect to erosion modelling, there are at least two important issues that have not yet been resolved satisfactorily. The first is the issue of flow concentration over the landscape. Natural hillslopes do not have planes Flows always occur in irregular rills or depressions. The density and dimension of these flow pathways determine the unit discharge which in turn is crucial to prediction of sediment concentration no matter which soil erosion model is considered. For erosion prediction using the concept of stream power (as in GUEST, LISEM and EUROSEM) or shear stress (WEPP), velocity and water depth are required, implying that a flow resistance equation, such as Manning's equation, must be used. Overland flow hydraulics is still an area of active research partly because the flow is neither laminar nor fully turbulent due to the presence of a bewildering array of resistance elements (Takken and Govers, 2000; Giménez and Govers, 2000). 


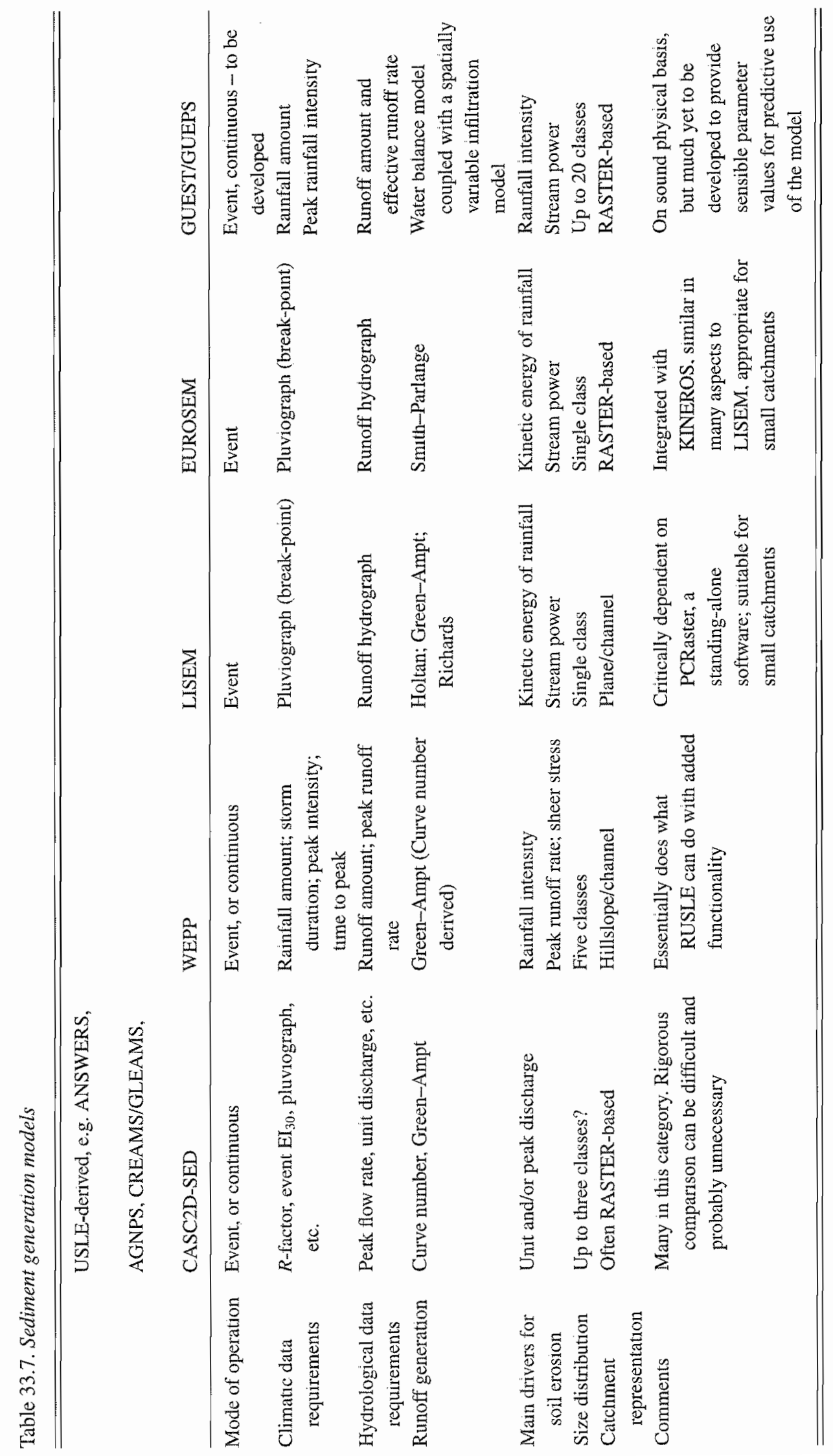




\section{Soil erodibility}

Soil erodibility is widely understood to represent the inherent susceptibility of the soil to erosional agents such as rainfall and runoff. The concept no doubt is sound. Measures of soil erodibility, however, depend on a particular conceptual framework in which soil erodibility is presented. In practice, soil erodibility usually represents what is unexplained and inexplicable. Consequently, the numerical value of the erodibility depends not only on the properties and the state of the soil, but also on the way in which soil erodibility is defined in a model. The net result is that the soil erodibility parameters for various models are likely to be incomparable. For example, Laflen et al. (1994) show that there was essentially no meaningful relationship between the USLE's $\mathrm{K}$ factor and the interrill and rill erodibility parameters of WEPP as determined using rainfall simulators. Furthermore, although the erosion equations themselves are physically based, the relationship describing the temporal variation of the erodibility parameters embedded in these equations is highly empirical because a complex sequence of land disturbances and the varying nature of these disturbances are inherently involved in changing the state of the soil in time. Bryan (2002) argued strongly that full understanding of the spatially variable and temporally dynamic (including variability within storm events) soil properties are essential to erosion predictions

\section{Unsteady rain}

Modelling of erosion, transport and deposition under unsteady rain is clearly needed At present, EUROSEM and LISEM consider unsteady rain but only use a single representative particle size. GUEST and WEPP, while taking into account sediment sorting due to contrasting settling velocities, are essentially steady-state models Realistic simulation of the dynamic processes of erosion, transport and deposition for a wide range of particle sizes is called for to represent the varied erosive forces in relation to a wide range of settling velocity characteristics during natural storm events.

Although in this critique a number of issues in relation to erosion modelling are highlighted, these are not meant to discourage the continued effort in developing, testing and validating physically based erosion models. Apart from its usefulness for erosion assessment and conservation planning, modelling provides an important link between theoretical work and practical outcomes Allowing some delay in time, many important concepts in erosion science will have themselves expressed in erosion models as our understanding of the processes and our ability to describe them quantitatively increase. In addition, modelling provides a framework to learn about the relative importance of different erosion processes (e.g. splash vs. wash or rill erosion; cf. van Dijk, 2002) and test various formulations of these processes. Erosion theory and modelling also provide a framework for experimental design and environmental monitoring programmes. For instance, for development and use of GUEST methodology, accurate measurement of runoff rate in addition to rainfall rate was regarded as essential because such data are required to determine soil erodibility parameters

\section{CONCLUSION}

Compared to the factor-based USLE/RUSLE, which has long been established and widely applied for soil erosion prediction, physically-based erosion models with a rather different approach to soil erosion modelling are now available to simulate various hydrological and erosion processes at a range of spatial scales. Common to most of these models is the considerable increase in their functionality in terms of dealing with complex topography and land use, sequences of management practices, realistic storm events and continuous weather sequences. More importantly, the physically-based models are capable of simulating spatial and temporal patterns of erosion as well as deposition. The latter is of considerable significance at the catchment scale. The ability to evaluate the effects of climate and land use change, as well as the changes in management practices, is the main attraction of this new generation of erosion prediction technology. The accuracy of the predictions by the physically-based models, even at the hillslope scale, is however yet to be fully demonstrated. In the humid tropics, use of these physically-based models certainly requires further calibration. However, routine application of physicallybased erosion prediction models in the tropics is unlikely in the near future, if only because of the cost involved. The cost of data collection for calibration, of developing a useful database for predictive use of models, and of training with respect to both using the model and interpreting the results will be prohibitive in most cases. Physically-based models are also inevitably limited by the empirical relationships that describe the variation of model parameters in space and time. Testing and validating these process-based models in diverse biophysical environments, notably in the humid tropics, are crucial to their long-term acceptance as a viable alternative to predict the rate of soil erosion routinely and operationally and to replace, if needed, factor-based models such as the USLE/RUSLE.

\section{References}

Abrahams, A D and Parsons, A J. (1994) hydraulics of interrill overland flow on stone-covered desert surfaces. Catena 23:111-140.

Agus, F, Gintings, A. N., Kunnia, U, Abdurachman, A and van der Poel, P. (1997) Soil erosion research in Indonesia: Past experience and future direction. In: F. W. T Penning de Vries, F. Agus and I Kerr (eds). Soil Erosion at Multiple Scales, CABI Publsihing, pp 255-267

Alberts, E. E., Nearing, M A., Weltz, M. A, Risse, L M ,Pierson, F. B , Zhang, X C., Laflen, J M and Simanton, J. R. (1995). Ch 7 Soil component $\mathrm{ln}$ D. C. Flanagan and M A. Nearing (ed.) USDA-Water Erosion Prediction 
Project: Hillslope Profile and Watershed Model Documentation. NSERL Report No. 10. West Lafayette, Ind: USDA-ARS Nat. Soil Erosion Research Laboratory

Bagnold, R A (1977) Bedload transport by natural rivers. Water Resour. Res 13:303-11.

Beasley, D. B , Huggins, L. F. and Monke, E. J (1980) ANSWERS: A model for watershed planning. Trans ASAE, 23(4), 938-944

Beuselinck L., Govers, G., Hairsine, P. B., Sander, G C. and Breynaert, M (2002a) The influence of rainfall impact on sediment transport by overland flow over areas of net deposition, J. Hydrol 257:145-163.

Beuselinck, L., Hairsine, P. B. Sander, G C and Govers, G (2002b) Evaluating a multi-class net deposition equation across a range of conditions. Water Resour Res 38(7), doi: 10.1029/2001 WR000250, 2002

Bingner, R. L. (1990) Comparison of the components used in several sediment yield models. Trans ASAE 33:1229-1238

Bjomeberg, D. I. , Trout, T J., Sojka, R E. and Aase, J K (1999) Evaluating WEPP-predicted infiltration, runoff, and soil erosion for furrow inigation Trans. the ASAE 42:1733-1741

Bouraoui, $F$ and Dillaha, T. A (1996) ANSWERS-2000: Runoff and sediment transport model $\mathrm{r}$. Env. Engg., ASCE, 122:493-502.

Bruijnzeel, L A (1990) Hydrology of moist tropical forests and effects of conversion. A state-of-knowledge review. UNESCO International Hydrological Ptogramme, Paris, $224 \mathrm{pp}$

Catena (1999) VoI 36, Issue 3-4, Special issue on 'Modelling soil erosion by water at the catchment scale.

Chu, S T (1978) Infiltration during unsteady rain. Water Resour Res. 14:461466

Ciesiolka, C. A. A., Coughlan, K. J., Rose, C. W., Escalante, M. C., Hasim, G. M, Paningbatin, E. P., Jr and Sombatpanit. S (1995). Methodology for a multi-country study of soil erosion management. Soil Tech 8: 179-192.

Cogle, A. L., Lane, L. J. and Basher, L. (2001) Testing the Hillslope erosion model for Application in India, New Zealand and Australia In MODSIM 2001, 10-13 December 2001, The Australian National University, Canberra, Australia, pp 173-178

Coughlan, K. J. and Rose, C. W. (Eds). (1997) 'A New Soil Conservation Methodology and Application to Cropping Systems in Ttopical Steeplands' ACIAR Technical Report No 40. (ACIAR: Canberra.)

De Roo, A P. J. (1998) Modelling tunoff and sediment transport in catchment using GIS. Hydrol Process: 12, 905-922

De Roo, A P. J and Jetten, V. G (1999) Calibrating and validating the LISEM model for two data sets from the Netherlands and South Africa. Catena 37: 477-493.

De Roo, A P. J., Offermans, R. J E and Cremers, N D T (1996b) LISEM A single-event physically based hydrological and soil erosion model for drainage basins. II Sensitivity analysis, validation and application. Hydrol Processes, 10:1119-1126

De Roo, A P. J., Wesseling, C. G. and Ritsema, C. J. (1996a) LISEM: A singleevent physically based hydrological and soil erosion model for drainage basins. I. Theory, input and output. Hydrol. Processes, 10:1107-1117.

De Roo, A. P. J., Wesseling, C. G. and Van Deursen, W. P. A. (2000) Physically based river basin modelling within a GIS; the LISFLOOD model Hydrol Proc. 14: 1981-1992

Dickinson, A. and Collins, R. (1998) Predicting erosion and sediment yield at the catchment scale. In: F. W. T. Penning de Vries, F Agus and J Kerr (eds) Soil Erosion at Multiple Scales, 317-342

Dietrich, W. E., Wilson, C. J, Montgomery, D. R., McKean, J. and Bauer, R. (1992) Erosion thresholds and land surface motphology. Geology 20: 675-679

Dunne, T (1978) Field studies of hillslope flow process In: M. I. Kirkby (ed ) Hillslope Hydrology Wiley, Chichester, 227-293.

El-Swaify, S. A and Dangler, E. W. (1977) Erodibility of selected tropical soils in relation to structural and hydrologic parameters. In Soil Erosion Prediction and Control, Soil and Water Conservation Society, Ankeny, Iowa, pp. 105-114

Everaert, W (1991) Empirical relations for the sediment transport capacity of interrill flows. Earth Surface Processes and Landforms 16:513-532

Favis-Mortlock, D T., Quinton, J. N . and Dickinson, W. T (1996) The GCTE validation of soil erosion models for global change studies J Soil and Water Conservation 51:397-403.
Fentie, B. (2001) Sustainability of the resource base in grazing lands, Queensland: Modelling erosion-productivity pf pasture lands. Unpubl. $\mathrm{Ph} \mathrm{D}$. thesis, University of Queensland

Fentie, B , Coughlan, K J and Rose, C W (1997) Manual for Use of Program GUEST30 Faculty of Environmental Sciences. (Griffith University: Brisbane.)

Fentie, B. Yu, B, Silburn, M. D and Ciesiolka, C. A A. (2002) Evaluation of eight different methods to predict hillslope runoff rates for a grazing catchment in Australia. J Hydrol 261:102-114.

Fisher, G. and Heilig, G. K. (1997) Population momentum and the demand for on land and water resources. Philosophical Transactions of the Royal Society of London, B352:862-869

Flanagan, D. C and Nearing, M. A. (Ed) (1995) WEPP Technical Documentation. NSERL Report No. 10. USDA-ARS-MWA: West Lafayette, IN

Flanagan, D. C. and Livingston, S. J. (Ed.) (1995) WEPP User Summary NSERL Report No. 11. USDA-ARS-MWA: West Lafayette, IN

Flanagan, D. C and Nearing, M A (2000) Sediment particle sorting on hillslope profiles in the WEPP model. Trans. ASAE, 43: 573-583

Flanagan, D. C., Renschler, C. S., Frankenberger, J R, Cochrane, T A, and Angel, B A (2001) Enhanced WEPP model applicability for improved erosion prediction. In MODSIM 2001, 10-13 December 2001, The Australian National University, Canberra, Australia, pp 1817-1822

Folly, A, Quinton, J. N and Smith, R. E. (1999) Evaluation of the EUROSEM model using data from the Catsop watershed, the Netherlands. Catena 37:507-519

Foster, G. R (1982) Modelling the erosion process. Chapter 8 in C. T Haan (ed). Hydrologic Modelling of Small Watershed. ASAE Monograph No 5 , pp. 297-360

Ghidey F and Alberts, E. E (1996) Comparison of measured and WEPP predicted runoff and soil loss for Midwest claypan soil . Trans. ASAE 39:13951402

Giménez, R. and Govers, G. (2001) Interaction between bed roughness and flow hydraulics in eroding rills. Water Resour. Res. 37:791-799

Govers, G (1990) empirical relationships for the transport capacity of overland flow. In erosion Transport and depositiion Processes, Proceedings of Jarusalem Workshop, 187 IAHS Publi No 189

Hairsine, P. B and Rose, C. W. (1991) Rainfall detachment and deposition: Sediment transport in the absence of flow-driven processes. Soil Sci Soc Am. J 55:320-324

Hairsine, P. B. and Rose, C. W. (1992a) Modelling water erosion due to overland flow using physical principles: I. Uniform flow. Water Resour Res. $28: 237-44$

Hairsine, P. B and Rose, C. W. (1992b) Modelling water erosion due to overland flow using physical principles: II. Rill flow. Water Resour Res 28:24550.

Hairsine, P B Sander, G C Rose, C W, Parlange, J-Y, Hogarth, W L, Lisle, I and Rouhipour, H (1999) Unsteady soil erosion due to rainfall impact: a model of sediment sorting on the hillslope J. Hydrol 220:115128

Haitsine, P. B., G. C. Sander, and L. Beuselinck. 2002. Sediment transport through an area of net deposition. Water Resour. Res. 38(6), 10 1029/2001 WR000265, 2002

Hancock, G R., Willgoose, G. R. and Evans, K. G. (2002) Testing of the SIBERIA landscape evolution model using the Tin Camp Creek, Northern Territory, Australia, field catchment Earth Surface Processes and Landforms $27: 125-143$

Hessel, R (2002) Adapting the LISEM model to Loess Plateau conditions. ISCO 2002, 26-31, May, Beijing, China, pp. 110-115.

Hogarth, W. L., Rose, C. W., Parlange, J. Y., Sander, G C and Carey, G. (2004) Soil erosion due to rainfall impact with no inflow: a numerical solution with spatial and temporal effects of sediment settling velocity characteristics. J. Hydrol 294(4): 229.

Holtan, H. N. (1961) A concept for infiltration estimates in watershed engineering ARS-4-51, Agricultural Research Service, USDA, $25 \mathrm{p}$

Huang, C., Wells. L. K. and Norton, L. D. (1999) Sediment transport capacity and erosion processes: Model concepts and reality. Earth Sufface Process and Landform 24:503-516

Jetten V, de Roo, A and Favis-Mortlock, D. (1999) Evaluation of field-scale and catchment-scale soil erosion model Catena 37:521-541 
Johnson, B. E , Julien, P. Y., Molnar, D. K and Watson, C. C. (2000). The twodimensional upland erosion model CASC2D-SED . J Amer. Water Resourc. Assoc. 36:31-42

Kandel, D. D, Western, A. W., Grayson, R. B and Turral, H. N. (2001) Testing current generation soil erosion models at two-minute and daily scales against plot scale data from mid-hill catchment of Nepal. In MODSIM 2001, 10-13 December 2001, The Australian National University, Canberra, Australia, pp . 173-178

Klik A., Hebel B, Zartl A. and Rosner J (1997) Measured vs WEPP simulated runoff and erosion from differently tilled plots In 'ASAE Annual International Meeting', $10 \mathrm{pp}$. (Minneapolis, MN).

Kincaid, D. C. (2002) The WEPP model for runoff and erosion prediction under sprinkler irrigation. Trans ASAE 45:67-72

Kinnell, P. I. A. (1997) Runoff ratio as a factor in the empirical modelling of soil erosion by individual rainstorms Aust J. Soil Res. 35:1-13

Kinnell, P. I A (1998) Converting USLE soil erodibilities for use with $\mathrm{Q}_{\mathrm{R}} \mathrm{EI}_{30}$ index. Soil and Tillage Res. 45:349-357.

Knisel, W. G. (1980) CREAMS: A field-scale model for chemicals, tunoff and erosion from agricultural management systems. USDA Conservation Research Repott No . 26. (USDA-ARS: Washington, DC)

Knisel, W. G. (1991) CREAMS/GLEAMS: A development overview. In Beasley, D. B, Knisel, W G. Rice, A. P. Eds. Proc. of the CREAMS/ GLEAMS Symposium, Publ 4, Agric Engineering, U. Georgia, Athens, p. 9-17.

Laffen, J. M., Elliot, W. I., Flanagan, D C., Meyer, C R and Nearing, M. A (1997) WEPP-Predicting water erosion using a process-based model. J Soil and Water Conserv 52:96-102.

Lal, R. (1990) Soil erosion in the tropics: Principles and management. McGraw Hill, New York

Lane L J., Renard K. G., Foster G R. and Laflen, J. M (1992) Development and application of modem soil erosion prediction technology - The USDA experience. Aust. J. Soil Res. 30:893-912.

Lane, L. J., Nichols, H. M. and Paige, G. B. (1995) Modelling erosion on hillslopes: Concepts, theory and data. In Proceddings of the International Congress on Modeliing and Simulation (MOSIM'1995), University of Newcastle, NSW, Australia, 1-7

Lisle, I. G, Coughlan, K. J., and Rose, C W. (1996) 'GUPRO 3.1: A Program for Calculating Particle Size and Settling Characteristics'. ENS Working Paper, 7/96. Faculty of Environmental Sciences. (Griffith University: Brisbane.)

Liu, B. Y, Nearing, M. A , Baffaut, C and Ascough, II J. C. (1997) The WEPP watershed model: III Comparison to measured data from small watersheds Trans the ASAE 40: 945-952.

Loch, R. J. and Rosewell, C. J. (1992) Laboratory methods for measurement of soil erodibilities (K-factor) for the Universal Soil Loss Equation. Aust J Soil Res 30:231-48

Lu, H., Gallant, J., Prosser, I. P., Moran, C. and Priestley G. (2001) Prediction of sheet and rill erosion over the Australian continent: Incorporating monthly soil loss distribution. Technical report 13/01, CSIRO Land and Water, Canberra, Australia

Myers, N. (1993) Gaia. An Atlas of Planet Management. Anchor and Doubleday, Garden City, NY

Misra, R K and Rose, C W. (1995) An examination of the relationship between erodibility parameters and soil strength Aust. J Soil Res. 33:71532

Misra, R. K and Rose, C. W. (1996) Application and sensitivity analysis of process-based erosion model GUEST. European Joumal of Soil Science 47:593-604.

Morgan, R. P. C, Quenton, J. N., Smith, R. E., Govers, G., Poesen, J. W. A., Auerswald, K., Chisci, G., Torri, D. and Styczen, M E. (1998) The European soil erosion model (EUROSEM): A dynamic approach for predicting sediment transport from fields and small catchments.. Earth Surface Processes and Landforms 23:527-544

Moss, A J. (1988) The effects of flow-velocity variations on rain-driven transportation and the role of raindrop impact in the movement of solids. Aust. J Soil Res 26:443-450

Mutchler, C. K., Murphree, C. E and McGregor, K. C. (1994) Laboratory and field plots for erosion research In R. Lal (ed.) Soil Erosion Research Methods, Soil and Water Conservation Society and St Lucie Press
Nash, I. E and Sutcliffe. J. V. (1970) River flow forecasting through conceptual models Part 1: A discussion of principles J Hydrol 10:282-90.

Nearing, M. A., Foster, G. R., Lane, L J and Finkner, S. C. (1989) A process based erosion model for USDA water erosion prediction project technology Trans ASAE 32:158-1593

Oldeman, L. R., Hakkerling, R. T. A and Sombroek, W. G (1991) 'World Map of the Status of Human-induced Soil Degradation: An Explanatory Note.' (International Soil Reference and Information Centre:Wageningen )

Onstad, C. A., and Foster, G. R. (1975). Erosion modelling on a watershed Trans. ASAE 18:288-92.

Penning de Vries, F. W. T., F. Agus and J Kerr (eds) (1998) Soil Erosion at Multiple Scales. CABi Publishing, Wallingford, UK

Popa, N (2002). Soil erosion models used in Romania. In ISCO 2002, 26-31, May 2002, Beijing, China, pp. 222-226

Povilaitis, A, Robichaud, P, Dumbrauskas, A., Tumas, R, Ruseckas, J and Heatwole, C (1995) Erosion prediction in the Republic of Lithuania with the WEPP model. In 'Water quality modelling: Proceedings of the International Symposium' pp 333-340 (Orlando, FL)

Proffitt, A P. B., Hairsine, P B and Rose, C. W. (1993) Modelling soil erosion by overland flow: application over a range of hydraulic conditions. Trans ASAE, 36:1743-1753.

Proffitt, A P. B., Rose, C. W. and Hairsine, P. B . (1991) Rainfall detachment and deposition: experiments with low slopes and significant water depths. Soil Sci. Soc. Am J 55:325-332

Quinton, J. N. and Morgan, R. P. C. (1998) EUROSEM: an evaluation with single event data from the C5 watershed, Oklahoma, USA In: Proceedings of the NATO Advanced Research Workshop 'Global change: modelling soil erosion by water', J. Boardman and D Favis-Mortlock (ed), $65-74$.

Renard, K. G ,Foster, G. A., Weesies, G. A., McCool, D. K., Yoder, D (1997) Predicting Soil Erosion by Water: A Guide to Conservation Planning with the Revised Universal Soil Loss Equation (RUSLE), USDA Agriculture Handbook No. 703, (US Gov. Print. Office: Washington DC.)

Renard, K. G, Foster, G. R., Weesies, G. A., McCool, D K and Yoder, D C coordinators (1997). Predicting Soil Erosion by Water: A Guide to Conservation Planning with the Revised Universal Soil Loss Equation (RUSLE), US Department of Agriculture, Agriculture Handbook No. 703, $404 \mathrm{pp}$

Roose, E (1977) Use of the Universal Soil Loss Equation to reduce erosion in West Africa. In Proceedings of the National Conference on Soil Erosion Soil Conservation Society of America, Ankeny, Iowa.

Rose, C. W. (1997) Modelling erosion by water and wind In Advances in Soil Science, Eds R. Lal, W. H Blum, C. Valentine, B A. Stewart. 57-88

Rose, C. W (1993) Erosion and sedimentation. In 'Hydrology and Water Management in the Humid Tropics - Hydrological Research Issues and Strategies for Water Management' (Eds M Bonnell, M. M Hufschmidt and J S Gladwell) pp. 301-43. (Cambridge University Press: Cambridge)

Rose, C. W. Coughlan, K J., Ciesiolka, C A A and Fentie, B (1997) Program GUEST (Griffith University Erosion System Template). In 'A New Soil Conservation Methodology and Application to Cropping Systems in Tropical Steeplands' (Eds K. J. Coughlan and C. W Rose) ACIAR Technical Report, No 40, pp. 34-58. (ACIAR: Canberra)

Rose, C. W., Williams, J. R., Sander, G C. and Barry D. A. (1983a) A mathematical model of soil erosion and deposition processes. I. Theory for a plane land element. Soil Sci Soc. Am J 47:991-995.

Rose, C. W., Williams, J. R, Sander, G. C and Barry, D. A. (1983b) A mathematical model of soil erosion and deposition processes II. Application to data from an arid-zone catchment Soil Sci Soc. Am J. 47:9961000

Rose, C W. and Yu, B. (1998) Dynamic process modelling of hydrology and soil erosion. In: F. W. T. Penning de Vries, F Agus, and J. Kerr eds. Soil Erosion at Multiple Scales. CAB Intennationals, 269-286.

Rose, C. W., Yu, B , Hogarth, W. L., Okom, A E. A., and Ghadiri, H (2002) Theoretical interpretation of the spatial and size distribution of sediment deposited by buffer strips from flow at modest land slopes J Hydrol. In review

Sander, G. C., Hairsine, P. B , Rose, C. W., Cassidy, D., Parlange, J. Y, Hogarth, W. L, Lisle, I (1996) Soil erosion due to rainfall impact during the early stages of a rainstorm J. Hydrol. 178:351-367. 
Sander, G. C., P. B Hairsine, L Beuselinck, and G Govers. 2002. Multiclass net deposition solutions. Water Resour. Res. 38(6), 10.1029/2001 WR000323, 2002

Schmidt, J. (1996) Entwicklung und Anwendung eines physikalisch begriundeten Simulationsmodells für die Erosion geneigter, landwirtschaftlicher Nutzflächen. Berïner Geographische Abhandlungen 61 Department of Geography of the Free University, Berlin

Schröder, A . (2000) WEPP, EuROSEM, E-2D: Results of applicatios at the plot scale. 199-250. In J Schmidt (ed.) Soil Erosion, Springer-Verlag, Berlin

Siepel, A. C., Steenhuis, T S., Rose, C W. Parlange, I.-Y and McIsaac, G. F (2002) A simplified hillslope erosion model with vegetation elements for practical applications. J Hydrol. 258:111-121.

Smith, R. E., Goodrich, D and Quinton, J. N (1995) Dynamic distributed simulation of water shed erosion: the KINEROS2 and EUROSEM models J. Soil Water Conserv. 50:517-520

Smith, R E and Parlange, J. (1978) A parameter-efficient hydrologic infiltration model. Water Resour. Res. 14:533-538

Soil Technology (1995). Special Issue: Soil Erosion and Conservation. Soil Tech 8:177-258

Soto, B and Diaz-Fierros, F. (1998) Runoff and soil erosion from areas of burnt scrub: comparison of experimental results with those predicted by the WEPP model Catena 31:257-270

Stolte, J, Chen, Y., Ritsema, C J , van den Elsen, E., Reijnders, J and Thompson, J. (2002) Calibration and up-scaling of an erosion model as a tool for farmers involvement to define alternative land use. ISCO 2002, 26-31, May Beijing, China, pp 218-221

Stone, J.. J., Lane, L. J , Shirley, E D and Hernandez, M (1995) Ch. 4 hillslope surface hydrology. In D . C. Flanagan and M. A. Nearing (ed ) USDAWater Erosion Prediction Project: Hillslope Profile and Watershed Model Documentation. NSERL Report No. 10. West Lafayette, Ind : USDA-ARS Nat. Soil Erosion Research Laboratory.

Su, N., Basher, L., Barringer, J and Doscher, C (1999) Reconstructing the patterns of sediment transport and related hydrological processes usirg the WEPP model. In MODSIM 1999, 6-9 December 1999, University of Waikato, New Zealand, pp. 209-213

Takken, I., Beuselinck, L, Nachtergaele, J, Govers, G., Poesen, J and Degraer, G. (1999) Spatial evaluation of a physically-based distributed erosion model LISEM Catena, 37:431-447

Takken, I and Govers G (2000) Hydr aulics of interrill overland flow on rough, bare soil surfaces Earth Surface Processes and I andforms 25:1387-1402

Tiwari, A. K., Risse, L. M., Nearing, M. A. (2000) Evaluation of WEPP and its comparison with USLE and WEPP Trans ASAE 43:1129-1135

Van Deursen, W P. A. (1995) Geographical information systems and dynamic models. Netherlands Geogr. Studies, $190,198 \mathrm{pp}$

van Dijk A I J M (2002) Water and sediment dynamics in bench-terraced agricultural steeplands in West-Java, Indonesia. Unpublished $\mathrm{Ph} \mathrm{D}$. thesis Free University, Amsterdam, The Netherland

van Dijk, A I. J M and Bruijinzeel, L. A (2001) Modelling runoff and soi loss from bench terraced hillslope in the volcanic uplands of west Java, Indonesia MODSIM 2001, 233-238

Van Dijk, A. I J. M., Bruijnzeel, L A and Meesters, A. G C. H (2002) Exponential distribution theory applied to splash detachment and transport experiments. Soil Sci. Soc. Amer J., in press

Vertessy, R. A., Wilson, C J, Silburn, D. M., Connoy, R D and Ciesiolka, C. A A (1990) Predicting erosion hazard areas using digital terrain analysis IASH Proc Int Symposium on Reseatch Needs and Applications to Reduce Erosion and Sedimentation in Tropical Steeplands. Suva, Fiji. Pp. 298-308

Wen, D. (1993) Soil erosion and conservation in China. In: World Erosion and Conservation, D Pimentel (ed ), Cambridge University Press pp 63-107.

Wesseling, C G, Karssenberg, D, P. A. Burrough, P. A and Van Deursen, W. P. A. (1996). Integrating dynamic environmental models in GIS: The development of a dynamic modelling language. Transactions in GIS 1:4048
Willgoose, G. R., R. L. Bras, and I Rodriguez-Iturbe (1991) A physically based coupled network growth and hillscope evolution model: 1 Theory Water Resour Res. 27:1671-1684

Williams, J. R. (1975) Sediment-yield prediction with universal equation using runoff energy factor. In 'Present and Prospective Technology for Predicting Sediment Yields and Sounces’. pp 244-52 (USDA-ARS-S-40)

Williams, J R, Renard, K G. and Dyke, P. T (1983) A new method for assessing the effect of erosion on productivity - The Epic model. J. Soil Water Conserv. 38: 381-383

Wilson, C. J., Carey, J. W., Beeson, P. C, Gard, M. O and Lane, L. J (2001). A GIS-based hillslope erosion and sediment delivery model and its application in the Cerro Grande burn area. Hydrol. Processes 15:29953010 .

Wischmeier, W. H and Smith, D. D (1965) Predicting Rainfall-Erosion Losses from Cropland east of the Rocky Mountains: Guide for Selection of practices for Soil and Water Conservation USDA Agriculture Handbook No 282 US Gov Print Office: Washington DC

Wischmeier, W. H and Smith, D. D (1978) Predicting Rainfall Erosion Losses A Guide to Conservation Plaming. USDA Agriculture Handbook No. 537 US Gov. Print Office: Washington DC

Woolhiser, D A , Smith, R. E and Goodrich, D C, (1990) KINEROS: A kinematic runoff and erosion model: documentation and user manual, USDA Agricultural Service, ARS-77.

Yalin, M. S. (1963) An expression for bed-load transportation. J Hydraulic Div, ASCE, 98(HY3):221-250.

Young, R A., Onstad, C. A, Bosch, D. D and Anderson, W P. (1989) AGNPS a nonpoint-source pollution model for evaluating agricultual watersheds J. Soil Water Cons. 44:168-173

Yu, B (1997) GOSH: A Program for Calculating Runoff Rates Given Rainfall Rates and Runoff Amount, User Guide and Reference Manual. ENS Working Paper, 2/97. (Faculty of Environmental Sciences, Griffith University: Brisbane.)

Yu, B. (2003) A unified framework for water erosion and deposition equations Soil Science Society of America Journal, 67: 251-257.

Yli, B., Cakurs U and Rose, C. W. (1998) An assessment of methods for estimating runoff rates at the plot scale. Trans. ASAE 41:653-61.

Yu, B, Ciesiolka, C A . A , Rose, C W and Coughlan, K. J . 2000) A validation test of WEPP to predict runoff and soil loss from a pineapple farm on a sandy soil in subtropical Queensland, Australia. Aust. J of Soil Res. 38:537554

Yu, B and Rose, C W (1997) GUEPS: A Program for Calculating the Soil Erodibility Parameter $\beta$ and Predicting the Amount of Soil Loss Usin GUEST Methodology ENS Working Paper 3/97. (Faculty of Environmental Sciences, Griffith University: Brisbane

Yu, B and Rose, C W. (1999) Application of a physically based soil erosion model in the absence of data on runoff rates: $I$. Theory and methodology Aust J Soil Res. 37:1-11

Yu, B , Rose, C W., Ciesiolka, C. C. A., Coughlan, K. J and Fentie, B (1997a) Toward a framework for runoff and soil loss prediction using GUEST technology, Aust J Soil Res., 35:1191-1212

Yu, B., Rose, C W., Coughlan, K I and Fentie, B (1997b). Plot-scale rainfallrunoff characteristics and modelling at six sites in Australia and South East Asia, Trans ASAE 40:1295-1303

Yu, B and Rosewell, C. J (2001) Evaluation of WEPP for runoff and soil loss prediction at Gunnedah, NSW, Australia Aust. J. Soil. Res 38: 11311145

Yu, B., Sajjapongse, A., Yin, D., Eusof, Z., Anecksamphant, C., Rose, C. W and Cakurs, U. (1999) Application of a physically based soil erosion model in the absence of data on runoff rates: II. Four case studies from China, Malaysia and Thailand. Aust J. Soil Res. 37:13-31

Zhang X. C., Nearing M A., Risse L. M. and McGregor, K. C. (1996) Evaluation of WEPP runoff and soil loss predictions using natural runoff plot data Trans. ASAE 39:855-863. 